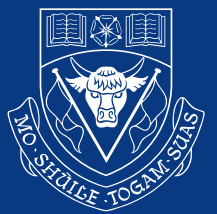

UNIVERSITY OF CALGARY

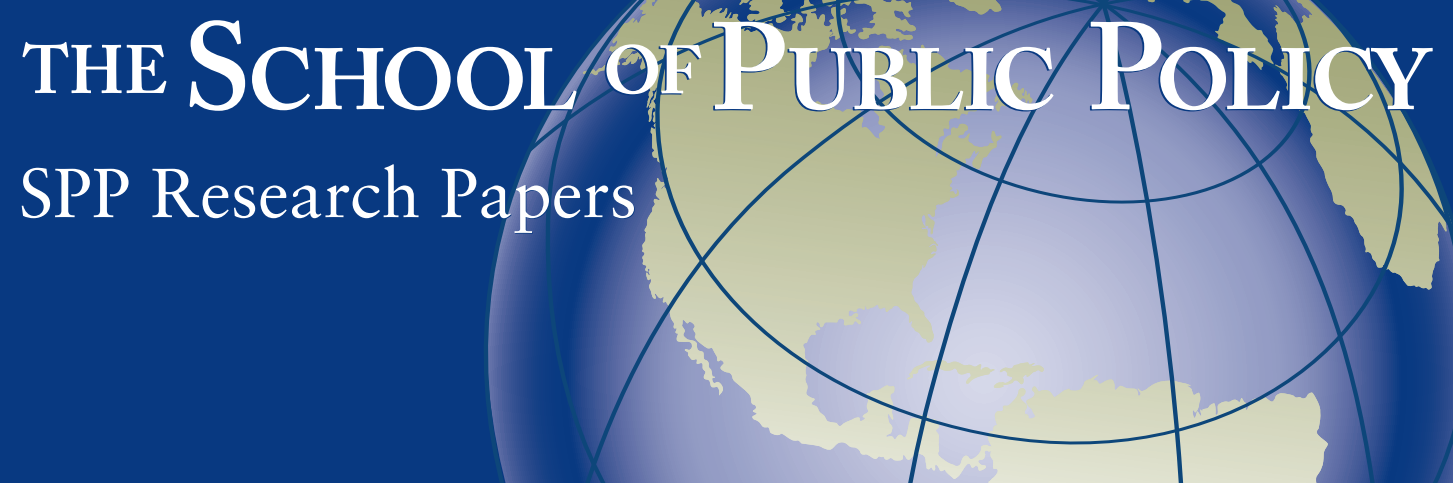

Volume 4 •Issue 15・December 2011

\title{
THE CONSTITUTIONALITY OF FEDERAL CLIMATE CHANGE LEGISLATION
}

\author{
Alastair R. Lucas and Jenette Yearsley*
}

\section{SUMMARY}

Over the last decade, the Canadian government has not managed to produce a comprehensive climate change statute and has failed to adequately consider the constitutional implications of doing so. The Clean Air Bill, an unsuccessful 2006 amendment to the Canadian Environmental Protection Act (CEPA), focused on carbon credit trading and a technology fund credit mechanism to permit certain emissions-heavy industries to mitigate their production of greenhouse gases. However, this bill would likely have infringed on provincial jurisdiction over electricity generation facilities, trumping any attempt to address greenhouse gas emissions beneath the rubric of criminal law. The present federal government's proposed coal-fired electricity generation regulations are similarly flawed. This paper thoroughly analyzes both pieces of legislation from a constitutional standpoint, using a rich body of case law to offer policymakers invaluable guidance in properly framing legally sound emission reduction statutes.

\footnotetext{
* Alastair R. Lucas, QC is Professor at the Faculty of Law, University of Calgary; Jenette Yearsley is Regulatory Counsel at AltaLink Calgary.
} 


\section{INTRODUCTION}

In 2002, Nigel D. Bankes and Alastair R. Lucas assessed the constitutionality of Alberta's Climate Change and Emissions Management Act. ${ }^{l}$ They concluded that there is a strong likelihood that it is intra vires the province, primarily as in relation to property and civil rights in the province under Section 92 (13) of the Constitution Act, 1867. The authors also ventured in a preliminary way to examine the federal government's potential ability to implement Canada's then-current climate change plan. But here the analysis could be no more than hypothetical limited to potentially relevant federal heads of power. Without legislation, or at least draft legislation, a full constitutional analysis was premature.

This article focuses on federal constitutional jurisdiction. The question is how detailed constitutional analysis would be applied to determine the validity of federal climate change legislation. The idea is to contribute to legal thinking about what constitutionally valid federal greenhouse gas (GHG) emission reduction legislation might look like. The ability of the federal government to exercise leadership in this complex and controversial area may depend on this, perhaps even in the face of very different provincial policies and legislation.

The specific target is the theory supporting federal jurisdiction based on an expansive federal criminal law power. While we do address potential federal jurisdiction under other heads of federal constitutional power to legislate, including the peace, order and good government and regulation of trade and commerce powers, the focus is criminal law. This is because of its recognized support for federal criminal prohibition and penalty provisions and the importance of prohibition-backed GHG emission targets, whatever form the legislation may take.

As will be seen, this constitutional analysis centres on statutory text and its context within the entire statute and related legislation and the broader societal context that led to its enactment (or potential enactment) in that particular form and in those particular words. The result is an overlong introduction and context that sets up and explains the specific legislation to be analyzed followed by a constitutional analysis that delves deeply into this internal statutory and external societal context. This is the kind of analysis a court would carry out. We have attempted in the article to closely follow this analytical process.

We still lack comprehensive, enforceable federal climate change legislation. But we do know a bit more than we did in 2002. Major climate change amendments to the Canadian Environmental Protection Act (CEPA) were introduced in 2006 (the amended Bill), but not ultimately enacted. In 2007, a Conservative minority government uncommitted to the Kyoto Protocol enacted the Kyoto Protocol Implementation Act, then failed to take regulatory action beyond monitoring and reporting under it. Then, in August 2011, the first set of sectoral regulations - for coal-fired electricity generation facilities - was published for comment in the Canada Gazette. ${ }^{2}$ The latter are based on existing CEPA authority. The text of these statutes and regulations are the best legislative data that we have. The current federal position ${ }^{3}$ emphasizes

l N. Bankes and A. Lucas, "Kyoto, Constitutional Law and Alberta's Proposals," (2004) 42 Alberta Law Review 355.

2 Government of Canada, "Notice concerning Proposed Reduction of Carbon Dioxide Emissions from Coal-Fired Generation of Electricity Regulations," Canada Gazette Part I, Vol. 145, No. 35, 27 August, 2011. [Proposed coal-fired electricity generation regulations].

3 See Government of Canada, Canada's Action on Climate Change www.climatechange.gc.ca. 
targeted regulations on a sector-by- sector basis to reduce GHG emissions by 17 percent below 2005 levels by 2020 . $^{4}$ Canadian action is intended, because of the integration of the Canadian and United States economies, to mirror initiatives (apparently including a cap and trade system) that the US may eventually take. However, as of 2011, climate change initiatives are not a high priority for the US federal government. Now it appears that Canadian federal legislation is likely to take the form of regulations under the Canadian Environmental Protection Act (CEPA). ${ }^{5}$

\section{WHY NOT ANALYZE THE KYOTO PROTOCOL IMPLEMENTATION ACT?}

The 2007 Kyoto Protocol Implementation Act $^{6}$ requires preparation of a climate change plan that describes measures to be taken and includes estimates of resulting GHG emission reductions as well as annual progress reports. However, this act does not itself mandate directly specific emission reduction actions. It does authorize regulations to impose certain requirements including limiting the amount of GHG releases and, "within the limits of constitutional authority," limiting GHG releases in provinces by applying Article 3 of the Kyoto Protocol, ${ }^{8}$ establishing performance standards, respecting trading in GHG emission reductions, respecting monitoring and inspection, and designating contraventions to be the subject of offences. No regulations have been made. More important, these regulation making powers provide only a menu of instruments. Unlike the amended Clean Air Bill, which established a price for carbon and proposed emission intensity-based caps for "large industrial emitters," particularly the coal-fired electricity generation and upstream oil and gas subsectors, the Kyoto Protocol Implementation Act lacks detail about the specific strategy, including instruments and processes that might actually be adopted. In August 2011, regulations under CEPA to regulate $\mathrm{CO}_{2}$ emissions from coal-fired electricity generation facilities were published for comment in the Canada Gazette. ${ }^{9}$ These regulations, intended to be implemented in 2015, indicate a policy shift from an emphasis on cap and trade instruments to GHG-emitter performance standard regulations. However, while cap and trade is rejected for the electricity generation sector because of the small number of facilities and marginal cost similarity, there is no clear indication that cap and trade has been abandoned for a wider spectrum of emission sources.

Consequently, this analysis will focus on the amended Clean Air Bill. But it will include some preliminary analysis of the proposed coal-fired electricity generation regulations.

\footnotetext{
4 In the Copenhagen Accord, December 2009. See supra note 2, Regulatory Impact Analysis. [Proposed coal-fired electricity generation regulations].

5 S.C. 1999 , c. 3.

6 S.C. 2007 , c. 30.

7 Ibid., s. 6(1)(a.1)

8 Kyoto Protocol to the United Nations Framework Convention on Climate Change, 11 December 1997, 2303 U.N.T.S. 148, 37 I.L.M. 22 (ratified by Canada 17 Dec. 2002, in force 16 February 2005).

9 Proposed Electricity Generation Regulations, supra note 2.
} 


\section{THE HOGG ANALYSIS}

This constitutional analysis will address in particular the work of Peter $\operatorname{Hogg}^{10}$ on federal constitutional competence to implement a GHG reduction scheme based on the 2008 Regulatory Framework for Industrial Greenhouse Gas Emissions. ${ }^{11}$ We recognize that Hogg's analysis is based not on the amended Clean Air Bill, but on the subsequent federal regulatory policy. Nevertheless, we question Hogg's conclusion that the federal criminal law power under s. 91(24) of the Constitution Act 1867 would necessarily support climate change legislation that includes mandatory GHG reduction as well as a compliance system featuring tradable emission reduction credits, offset credits resulting from other emission-reducing activities and credits based on contributions to a technology fund. Instead, we turn to the development of federal GHG-reduction policy and choose to base our analysis on the CEPA amendments (the amended Clean Air Bill) that were proposed in 2006 and the 2011 proposed CEPA coal-fired electricity generation regulations.

\section{FEDERAL CLIMATE POLICY}

The federal government's policy on climate change has undergone a metamorphosis since Canada ratified the Kyoto Protocol in 2002. ${ }^{12}$ Canada committed to a six percent reduction in GHGs over 1990 levels during the 2008-2012 period. This target proved to be overly ambitious. While Canada is a comparatively small contributor to global GHG emissions (about two percent), it is among the highest in terms of per capita emissions. ${ }^{13}$ By 2008, Canada's GHG emissions were 24 percent above 1990 levels. ${ }^{14}$ As it became apparent that voluntary measures and public education were inadequate to the task of reducing Canada's GHG emissions, the federal government incorporated regulatory instruments in an attempt to meet its Kyoto obligations. Now the federal government's stance on Kyoto has changed but it is likely that there will be legislation (most likely in the form of regulations) on the subject of climate change.

The first explicit sign that CEPA was the federal instrument of choice was the publication of a federal notice of intent ${ }^{15}$ to regulate Large Final Emitters (LFEs) under the 2005 Climate Change Plan. ${ }^{16}$ This action was directed toward meeting Canada's commitment under the

\footnotetext{
10 Peter Hogg, "Constitutional Authority over Greenhouse Gas Emissions" (2009) 46 Alta.L.Rev. 207; "A Question of Parliamentary Power: Criminal Law and the Control of Greenhouse Gas Emissions", C.D. Howe Institute Backgrounder, August 2008.

11 Environment Canada, "Regulatory Framework for Air Emissions" (Ottawa: Minister of Environment, 2007) .

12 Supra note 8.

13 Environment Canada, "A Climate Change Plan for the Purposes of the Kyoto Protocol Implementation Act - 2007" (Ottawa: 2007) at 1.

14 Environment Canada, "A Climate Change Plan for the Purposes of the Kyoto Protocol Implementation Act" (Ottawa: 2010) at 31.

15 Notice of Intent to regulate greenhouse gas emissions by Large Final Emitters, Canada Gazette 2005.I. 2489 (Canadian Environmental Protection Act, 1999), [Notice of Intent], online: http://gazette.gc.ca/archives/p1/2005/2005-07-16/html/notice-avis-eng.html\#i3.

16 Government of Canada, "Moving Forward on Climate Change: A Plan for Honouring our Kyoto Commitment" Project Green (Ottawa: 2005). A review of the plan is found in Alastair R. Lucas, "Mythology, Fantasy and Federalism: Canadian Climate Change Policy and Law" (2007) 20 Pac. McGeorge Global Bus. \& Dev. L.J. 41.
} 
Kyoto Protocol. The federal notice of intent was followed by a posting on the Environment Canada website containing "Drafting Instructions" for implementing regulations. ${ }^{17}$ Legislation was enacted to support the administrative and subsidy elements of the federal climate change plan. This was the Canadian Emission Reduction Incentives Agency Act, ${ }^{18}$ which established a climate fund (from the private purchase of emission credits) and created a new administrative agency to oversee it, and the Greenhouse Gas Technology Investment Fund Act, ${ }^{19}$ which established a technology fund and provided for its administration.

In October 2006, the federal government tabled Bill C-30, entitled "An Act to amend the Canadian Environmental Protection Act, 1999, the Energy Efficiency Act and the Motor Vehicle Fuel Consumption Standards Act (Canada's Clean Air Act). ${ }^{20}$ At the same time, a notice of intent to "develop and implement regulations and other measures to reduce air emissions" was published..$^{21}$ Bill C-30 was extensively revised in Committee. The resulting revised bill did not progress through the legislative process ${ }^{22}$ and eventually died on the order paper.

In spite of the legislative stalemate, the federal government, in April 2007, replaced its 2005 climate change plan with a new policy entitled "Turning the Corner: An Action Plan to Reduce Greenhouse Gases and Air Pollution." ${ }^{23}$ The Turning the Corner Plan is based on the notice of intent and was touted as the cornerstone of the government's efforts to address climate change and air pollution. The details of the plan were outlined in the Regulatory Framework for Air Emissions. ${ }^{24}$ The reason for the policy change became clear when the government announced that while it was not formally withdrawing from the Kyoto Protocol, its commitment to meet the emission targets under the Protocol were over. ${ }^{25}$ The government stated its intention to rely on a domestic plan - the Turning the Corner Plan - to tackle climate change.

The government fleshed out its climate policy by tabling additional documents in March 2008 including: (i) Taking Action to Fight Climate Change; (ii) Regulatory Framework for Industrial Greenhouse Gas Emissions; (iii) Canada's Offset System for Greenhouse Gases; (iv) Canada's Credit for Early Action Program; and (v) Detailed Emissions and Economic Modelling. ${ }^{26}$

17 Environment Canada "Drafting Instructions Cross-Cutting Provisions Large Final Emitters Regulations" CEPA Environmental Registry, online: http://www.ec.gc.ca/CEPARegistry/documents/part/LFE_drft_inst/LFE_drft_inst.cfm

18 S.C. 2005 , c. 30, s. 87 . This act is not yet in force.

19 S.C. 2005 , c. 30, s. 96.

$201^{\text {st }}$ Sess., $39^{\text {th }}$ Parl., 2006. Provocatively parenthetically titled, "Canada’s Clean Air Act".

21 Notice of Intent, supra note 15.

$221^{\text {st }}$ Sess., $39^{\text {th }}$ Parl., 2006 (as amended by the Legislative Committee on Bill C-30 as a working copy for the use of the House of Commons as Report Stage and as reported to the House on March 30, 2007) [Amended Clean Air Act].

23 Environment Canada News Release, "Canada's New Government Announces Mandatory Industrial Targets to Tackle Climate Change and Reduce Air Pollution", (Toronto April 26, 2007), online: http://www.ec.gc.ca/default.asp?lang=En\&n=714D9AAE-1\&news=4F2292E9-3EFF-48D3-A7E4-CEFA05D70C21.

${ }^{24}$ Government of Canada, "Regulatory Framework for Air Emissions", (Minister of Environment, 2007) [Air Emissions Framework], online: http://www.ec.gc.ca/doc/media/m_124/p1_eng.htm.

25 CBC News, "Canada will not withdraw from Kyoto: Baird" (October 19, 2007), online: http://www.cbc.ca/canada/story/2007/10/19/baird-kyoto.html?ref=rss\#ixzz0nGhsUTzV.

26 Environment Canada News Release, "Government Delivers Details of Greenhouse Gas Regulatory Framework", (Ottawa: March 10, 2008), online: http://www.ec.gc.ca/default.asp?lang=En\&n=714D9AAE-1\&news=B2B42466B768-424C-9A5B-6D59C2AE1C36. 
Subsequently however, the state of the federal policy was uncertain. The federal ecoAction website stated:

In April 2007, we announced Turning the Corner, however, following the economic downturn and the renewed engagement by the new US administration, we took the opportunity to fine-tune our approach to tackling climate change."27

The results included: (i) increasing the amount of electricity provided by non-emitting sources; (ii) new regulations on automotive emissions; (iii) continuing the Clean Energy Dialogue with the US administration; (iv) investing money from the Economic Action Plan into projects to protect the environment; and (v) participating at the UN climate change talks. Even with this new focus, the government did not appear to have scrapped the Turning the Corner policy. In the summer of 2009, Environment Minister James Prentice announced that Canada was moving toward a carbon market by developing an offset system for GHGs. ${ }^{28}$

Although the Turning the Corner Plan has not survived in its original form, it still provides part of the context in which to analyze constitutionally the federal climate change legislation as it developed. ${ }^{29}$ The starting point for understanding this context is the notice of intent.

\section{A Closer Look at the Federal Approach to Climate Change}

\section{A. THE NOTICE OF INTENT}

The notice of intent took a multi-pollutant approach to the regulation of GHGs and air pollutants (collectively air emissions). Underlying this approach was a recognition of the significant threat to Canadians' health posed by air pollutants and the contribution of anthropogenic GHGs to climate change..$^{30}$ A further factor was commonality of emission sources. The major sources of air emissions that cause smog and acid rain also produce a significant proportion of the anthropogenic GHG emissions. A multi-pollutant strategy involved coordinated requirements that allow sources to maximize synergies and cost efficiencies. It also allowed Canada to align its efforts with those of other industrialized countries - particularly the US.

27 Government of Canada, ecoAction, online: http://ecoaction.gc.ca/climatechange-changementsclimatiques/indexeng.cfm. The federal government focused on a clean energy dialogue with the US, Environment Canada News Release "Canada and the U.S. work together on Clean Energy Dialogue," (Ottawa: June 30, 2009), online: http://www.ecoaction.gc.ca/news-nouvelles/20090630-eng.cfm. Details on the Clean Energy Dialogue can be found online at: http://climatechange.gc.ca.

28 Environment Canada News Release "Offset System A Step Towards A Carbon Market In Canada" (Ottawa: June 10, 2009), online: http://www.ec.gc.ca/default.asp?lang=En\&n=714D9AAE-1\&news=23C6502E-4307-4647-A5C738B3B7EDDDF0. Details of the proposed offset system rules can be found online at: http://www.ec.gc.ca/creditscompensatoires-offsets/default.asp?lang=En\&n=0DCC4917-1 .

29 Notice of Intent, supra note 15 at 9.4 .

30 Notice of Intent, supra note 15 at 4. 
There were hints of constitutional advice in the language of the notice of intent. It noted that the federal government took responsibility to introduce an integrated, nationally consistent approach to reduce air emissions in order to protect the health of Canadians and the environment and to avoid falling further behind Canada's trading partners. ${ }^{31}$ There was also a statement that "reducing air emissions is a matter of national concern" since Canada's performance on air emissions lags behind most OECD countries. ${ }^{32}$ Thus, we had broad references to health and environment, judicially recognized as at least potentially valid federal criminal law power objectives, and explicit peace, order and good government power language of "national concern."

The regulatory approach under the notice of intent was to develop and implement regulatory measures primarily, but not exclusively, under $C E P A .{ }^{33}$ This was the purpose of the amended Clean Air Bill. The bill would also amend the Energy Efficiency Act $t^{34}$ and the Motor Vehicle Fuel Consumption Standards Act. ${ }^{35}$ This indicated the government's intention to regulate all major sources of air emissions including transportation, industrial emissions, consumer and commercial products and indoor air. ${ }^{36}$ More specifically the government intended to take the following actions:

- Harmonize Canadian vehicle emissions standards with the US Environmental Protection Agency (EPA);

- Support the development of international standards for emissions for aviation and shipping;

- Support emission standards for rail that are consistent with US EPA standards;

- Reduce volatile organic compounds from various consumer and commercial products and align requirements with the US;

- Establish or strengthen energy efficiency requirements for residential and commercial products;

- Develop a regulatory framework for industrial air emissions sources.

The last item - a regulatory framework for industrial air emissions - was expected to include short, medium and long-term emissions goals. This process of goal-setting involved consultations between the federal government and provinces, territories, affected sectors and other stakeholders. The government expected that this would provide flexible compliance options such as industry-led emissions trading, opt-in mechanisms, incentives for investment in technology such as carbon capture and storage and credit for early action and offsets. A key mechanism was to be the establishment of a technology investment fund to which industry and government could contribute in order to promote the development of transformational technologies.

\footnotetext{
31 Ibid. at 1.

32 Ibid.

33 Ibid. at 3.

34 S.C. 1992 , c. 36.

35 R.S.C. 1985, c. M-9.

${ }^{36}$ Notice of Intent, supra note 15 at 5-9.
} 
Finally, the notice of intent addressed the relationship between federal and provincial regulation. ${ }^{37}$ The intention was that the federal Ministers of the Environment and Health would engage their provincial counterparts with a view to entering into equivalency or administrative agreements. Equivalency agreements, specifically provided for in CEPA, ${ }^{38}$ permit CEPA regulations to withdraw in favour of provincial equivalents where there is rule and enforcement equivalency and provincial law includes a mechanism for citizen enforcement requests. Work on these agreements would take place alongside work on the development of federal regulations so that both federal and equivalent provincial regimes would be designed to achieve the same outcome and take effect at the same time. The result would be a common national regulatory approach.

In 2005, the federal cabinet made an order under section 332(1) of CEPA that added $\mathrm{CO}_{2}$ and five other GHGs to CEPA's Schedule I List of Toxic Substances. The order explained that an assessment, which relied on the Third Assessment Report of the Intergovernmental Panel on Climate Change, confirmed that these substances met the CEPA section s. 64 toxicity criteria, namely (a) harmful effect on the environment, (b) danger to the environment on which life depends, and (c) danger in Canada to human life or health. As Schedule 1 substances these GHGs could then be the subject of comprehensive regulations under CEPA, section 93(1).

\section{B. BILL C-30: THE CLEAN AIR ACT}

Bill C-30 was introduced in the House of Commons and given first reading on October 19, 2006. Canada's Clean Air Act was a set of amendments targeted primarily at CEPA. ${ }^{39}$ It did not mention the Kyoto Protocol and it did not set any firm limits on GHG emissions. The original bill was rejected by all opposition parties and was not approved in principle by the House of Commons. By agreement, it was referred to committee before the second-reading stage. The Legislative Committee on Bill C-30 effectively rewrote the bill to emphasize the action necessary to fulfil Canada's Kyoto obligations. There was no second reading or debate on the revised bill.

The original version of the Clean Air Bill defined "air pollutant" and "greenhouse gas." ${ }^{40}$ It removed both air pollutants and GHGs from Part 5 of CEPA and moved them into a new Part 5.1: "Clean Air." The purpose of Part 5.1 was "to promote the reduction of air pollution and to promote air quality in order to protect the environment and the health of all Canadians, especially that of the more vulnerable members of society." Part 5.1 allowed the government to issue guidelines, gather information, publish projections of air pollution or air quality and to create regulations. The only mandatory requirement was to create national air quality objectives for respirable particulate matter and ozone. ${ }^{41}$

\footnotetext{
37 Ibid. at 9.4 .

38 CEPA, s.10.

39 Canada, Library of Parliament, Bill C-30: Canada's Clean Air and Climate Change Act by Frédéric BeauregardTellier et al., Legislative Summary, LS-539E (Ottawa: Parliamentary Information and Research Service, 14 November 2006, Revised 19 April 2007).

40 Canada's Clean Air Act, supra note 22, s. 3.(2). The bill expanded the definition of "air" to include indoor air.

41 Ibid., s. 103.07.
} 
The amended Clean Air Bill is significantly different from the original text. ${ }^{42}$ The committee changed the title to "Canada's Clean Air and Climate Change Act" and included a reference to Kyoto in the preamble. Similar to the original bill, the amended bill recognized that air pollution and GHG emissions are of national and international concern. ${ }^{43}$ This was softened by an explicit statement that the federal government recognizes that air pollution and GHGs are "matters within the jurisdiction of both the Government of Canada and the governments of the provinces."

In the amended Clean Air Bill, air pollutants and GHGs were defined as substances that appear in Schedule 1 to CEPA (List of Toxic Substances). It also set out a more comprehensive system to reduce GHG emissions. The amended bill defined new terms including "carbon credit," "carbon permit," "domestic offset system" and "sectoral carbon budget". It set a carbon price that would increase from $\$ 20$ in 2008 to $\$ 30$ in 2011. Perhaps the most significant change was the addition of three new parts to CEPA: Part 5.1 on Climate Change Action; Part 5.1.1 on Greenhouse Gases; and Part 5.2 on Ambient Air Quality Standards and Emissions Standards.

Part 5.1 sets mandatory caps for GHGs starting in 2020 rather than the intensity-based caps proposed in the Notice of Intent. Targets for large industrial emitters ${ }^{44}$ were based on sector specific carbon budgets set at six percent below 1990 levels. These budgets must take into account early action by emitters and allow emitters to transfer and trade permits and purchase offsets. They must also ensure "fair treatment" for emitters whose rate of growth exceeds the average rate of growth for the sector. ${ }^{45}$

Part 5.1.1 establishes a territorial approach for GHGs that is compatible with federal-provincial equivalency agreements under s.10 of CEPA. The amended bill would not apply within the jurisdiction of another government that has enacted legal provisions that are "equivalent to the reductions required by the national carbon budget" and provisions equivalent to those in CEPA for the investigation of alleged offences. ${ }^{46}$ The amended bill also strengthened the requirements for air pollution under Part 5.2. Ambient air quality standards must be issued for each air pollutant within six months of the provision coming into force. The Environment Minister would divide the country into geographical zones and issue standards for each zone.

Ultimately, no further legislative action was taken on the amended Clean Air Bill, but policy action continued. The next move was by the federal government which announced its Turning the Corner Plan in 2007. This plan was based on the notice of intent and was followed by additional policy papers in March, 2008. Two of those policy papers are relevant here. These are the Regulatory Framework for Air Emissions and the Regulatory Framework for Industrial Greenhouse Gas Emissions.

\footnotetext{
42 Amended Clean Air Bill, supra note 22.

43 Ibid., Preamble.

44 Large industrial emitters are those particularly responsible for a large portion of Canada's GHG emissions including the electricity generation sector, upstream oil and gas sector and energy-intensive industries, Ibid., s. 103.05.

45 Ibid., s. 103.02.

46 Ibid., s. 103.051.
} 


\section{THE REGULATORY FRAMEWORK FOR AIR EMISSIONS ${ }^{47}$}

Like the notice of intent, the Air Emissions Framework was based on reducing emissions intensity in key parts of Canada's industrial sector. The policy was not directed at meeting Canada's commitment under Kyoto but rather started Canada "on the road to making real progress towards its Kyoto commitments. ${ }^{48}$ Free from Kyoto, the government adopted 2006 as its base year for emission intensity targets rather than the Kyoto base year of 1990.

The policy distinguishes between existing facilities and new facilities. Existing facilities would be required to make a six percent improvement each year (from a 2006 base level) beginning in 2007. Since the regulations were not in place, the policy considered these reductions unenforceable until 2010. Existing facilities were expected to achieve a cumulative 18 percent reduction in emissions intensity by that time. The government did not enforce these targets but it has not stated that it has abandoned the general approach.

New facilities were treated differently. A new facility was one whose first year of operation is 2004 or later. New facilities would have a three-year grace period after coming on stream before being required to reduce their emissions intensity. After that, the new facility would be required to improve its emission intensity by two percent a year. The initial target for the facility would be based on so-called "clean-fuel standards" which in most cases would likely be the emissions profile that would result if the facility were to use natural gas.

The Air Emissions Framework held that regulated emitters would be able to comply with their targets in a number of ways. These included: (i) actual reductions in emissions; (ii) contributions to a "climate technology fund"; and (iii) emissions trading.

Contributions to the climate technology fund would be at the rate of $\$ 15$ per tonne from 2010 through 2012 and $\$ 20$ per tonne effective 2013, escalating each year thereafter at the rate of growth of nominal GDP. A regulated emitter would not be able to meet its entire reduction commitments through this mechanism but would be subject to an initial cap of 70 percent. This cap would fall to zero in 2018 at which point contributions to the fund would no longer be available as a compliance option.

Emissions trading could be used in several ways to meet emissions targets. These options include: (i) trading between firms; (ii) purchasing credits through the Kyoto Protocol Clean Development Mechanism (to a maximum of 10 percent per firm) and (iii) purchasing credits through a domestic offset system. The offset system could link to other trading systems both in North America and globally.

\footnotetext{
47 Supra note 4. Commentators observed that despite mutual criticism by the governments and calls for new approaches, the 2007 plan bears an odd resemblance to the 2005 climate change plan: Shi-Ling Hsu \& Robin Elliot, "Regulating Greenhouse Gases in Canada," (2009) 54 McGill L.J. 463 at para 12.

48 Ibid. at 4.
} 


\section{THE REGULATORY FRAMEWORK FOR INDUSTRIAL GREENHOUSE GAS EMISSIONS ${ }^{49}$}

The basic elements of the GHG Emissions Framework remained the same as those of the Air Emissions Framework. The GHG Framework expected existing facilities to reduce their emissions intensity by 18 percent in 2010 and a further two percent for each following year. Targets could be facility-specific, sector-wide or corporate. Facility-specific targets would be applied in sectors where there are factors beyond the control of a facility operator that affect emissions $^{50}$ and in sectors with complex and diverse facility structures. Facility-specific targets will be applied in the following sectors: iron ore pelletizing, potash, base metal smelting, chemicals, fertilizers, iron and steel, ilmenite (titanium), oil sands, petroleum refining, natural gas pipelines and upstream oil and gas.

Sector-wide targets would be used in sectors where facility structures are less complex and more homogeneous. Those were the lime, pulp and paper, aluminum and alumina and cement sectors. Finally, corporate-specific targets would be used in the electricity sector because this would provide an incentive for investment in new clean and low-emission power generation. The framework provided an exclusion for fixed process emissions for both existing and new facilities. Fixed process emissions were emissions tied to production where there is no reduction technology currently available.

The definition of a "new" facility was expanded. In the Air Emissions Framework, new facilities were defined as those whose first year of operation was 2004 or later. The GHG Emissions Framework expanded that definition to include major expansions or transformations of existing plants. Only the expanded or transformed portion of the facility would be treated as new, unless the integrated nature of the facility required that the entire facility be treated as new. Re-opened facilities would typically be treated as existing facilities.

Not all facilities were subject to regulation. The GHG Emissions Framework contemplated targeting major industrial sectors. Targets would apply to chemical, fertilizer and natural gas pipeline operations that emit more than $50,000 \mathrm{CO}_{2}$ e per year, to electricity generators of more than $10 \mathrm{MW}$ per year and to upstream oil and gas facilities with minimum emissions of 3,000 $\mathrm{CO}_{2} \mathrm{e}$ and 10,000 BOE/day/company. This coverage plan was not set in stone. The framework contemplated further discussions with the provinces in order to seek "a common practical approach to emissions coverage." 51

The menu of compliance options was more developed. The choices included: a technology fund, inter-firm trading, an offset system, a clean development mechanism and a one-time credit for early action. Each of these is discussed in turn.

Technology Fund: In the initial years, industry would be able to meet a significant part of its regulatory obligations by contributing to the technology fund. Each year the cost of contribution to the fund $\left(\$ /\right.$ tonne $\left.\mathrm{CO}_{2} \mathrm{e}\right)$ would rise while the number of credits a firm may

\footnotetext{
49 Government of Canada, "Regulatory Framework for Industrial Greenhouse Gas Emissions", (Minister of Environment, March 2008) [GHG Emissions Framework], online: http://www.ec.gc.ca/doc/virage-corner/200803/541_eng.htm.

50 Ibid., Section 2.1, "Targets". (e.g. terrain characteristics, elevation, configuration, and diameter of pipe).

${ }^{51}$ Ibid., Section 3, "Consultations".
} 
obtain falls. In this way, the technology fund would eventually be eliminated as a compliance option. ${ }^{52}$ Money in the fund would be invested in qualifying GHG emission-reduction technology projects. These projects could result in an inter-regional transfer of wealth.

In some cases, firms would have an alternative to contributing directly to the technology fund. Under the pre-certified investment option, a firm could receive credits for investing directly in large-scale transformative projects selected from a menu set out by the federal government. Carbon capture and storage was the only project type that qualified as a pre-certified investment option.

There was a possibility that contributions to provincial funds could be used to meet federal targets. A firm contributing to a recognized provincial fund would be eligible to receive credits, at the contribution rate and up to the contribution limit, in the federal plan. The decision to recognize a provincial fund would be the responsibility of the federal government. To ensure a nationally consistent approach, other funds would be required to have a mandate and criteria equivalent to those governing the federal technology fund.

Inter-firm trading: Firms whose actual emission intensity in a given year is below their target would receive tradable credits equal to the difference between their target and their actual emission intensity, multiplied by their production in that year. These credits could be banked for future use or sold to other regulated entities.

Offset scheme: Offsets were projects undertaken by non-regulated entities that result in incremental real, verified domestic reductions or removals of GHG emissions. These projects would generate credits that regulated entities could use to meet targets. After publication of the GHG Emissions Framework, the federal government developed the rules for the offset system. ${ }^{53}$ Three draft guides - Guide for Protocol Developers; Program Rules and Guidance for Project Proponents; and Program Rules for Verification and Guidance for Verification Bodies - were published in the Canada Gazette..$^{54}$

The first guide - the Guide for Protocol Developers - provided the rules and offered guidance on the requirements and processes to complete an offset system quantification protocol. The quantification protocol described the approach that must be used to quantify the GHG reductions for a specific project type. Protocols could be fast-tracked if the protocol is a complete document that has been approved for use by the Kyoto Protocol Clean Development Mechanism, Alberta's Specified Gas Emitters Regulation, ${ }^{55}$ the California Climate Action Registry, the Greenhouse Gas Abatement Scheme in New South Wales, France's Offset System, or the North American Regional Greenhouse Gas Initiative. ${ }^{56}$

52 Ibid., Section 2.2, "Compliance Mechanisms"; Section 5.1, "Technology Fund".

53 Minister of the Environment, "Canada's Offset System for Greenhouse Gases, Overview: Draft for Public Comment" (Ottawa: 2009), online: http://www.ec.gc.ca/creditscompensatoires-offsets/default.asp?lang=En\&n=92CA76F4-1.

54 Notice of intent to publish Canada's Offset System for Greenhouse Gases: Guide for Protocol Developers as one of three proposed Guides under Canada's Offset System for Greenhouse Gases, C. Gaz. 2008.I.2410 (Canadian Environmental Protection Act, 1999); Notice of intent to publish Canada's Offset System for Greenhouse Gases: Program Rules and Guidance for Project Proponents and Canada's Offset System for Greenhouse Gases: Program Rules for Verification and Guidance for Verification Bodies as two of three proposed guides under Canada's Offset System for Greenhouse Gases, C. Gaz. 2009.I.1698 (Canadian Environmental Protection Act, 1999). All guides are available online: http://www.ec.gc.ca/creditscompensatoires-offsets/default.asp?lang=En\&n=0DCC4917-1.

55 Alta. Reg. 139/2007.

56 Canada's Offset System for Greenhouse Gases Guide for Protocol Developers, supra note 54 Annex J. 
The second guide - the Program Rules and Guidance for Project Proponents - provided the rules and offered guidance on the requirements and processes to create offset credits, from the registration of the project to the issuance of offset credits. The third guide - the Program Rules for Verification and Guidance for Verification Bodies - set out the rules and offered guidance on the requirements and processes to verify the eligible GHG reductions or removals achieved from a registered project. The federal government planed to administer the offset system as a voluntary program under s. 322 of $C E P A .{ }^{57}$

Clean Development Mechanism: Firms could use certain credits from the Kyoto Protocol's Clean Development Mechanism to meet emissions targets. Access to these credits for compliance purposes would be limited to 10 percent of the firm's total target.

One-time credit for early action: Firms that took verified action between 1992 and 2006 to reduce their GHG emissions would be potentially eligible for a share of a one-time credit for early action. The program allowed a one-time allocation of credits up to a maximum of $15 \mathrm{Mt}$. The credits were bankable and tradable.

A major feature of the GHG Emissions Framework was the promotion of carbon capture and storage (CCS). This was done in several ways. First, certain new facilities commencing operations in 2012 or later will face additional target requirements based on CCS. These targets will apply starting in 2018. Facilities covered by these additional requirements include in situ oil sands facilities, upgraders and coal-fired power plants. Second, new facilities commencing operations in 2004 or later in the oil sands, electricity, petroleum refining, chemicals and fertilizer sectors would not have to comply with the more stringent clean fuel standards until 2018 provided they are built CCS-ready. Third, a firm could meet 100 percent of its regulatory obligation by investing in CCS projects in the oil sands and coal-fired electricity sectors. This option was limited to firms in the oil sands, electricity, chemicals, fertilizers and petroleum refining sectors.

It is clear that the federal policy on climate change extended far beyond simply setting limits on GHG emissions. But the important point of this analysis is that all of this was only policy. There was no regulatory framework, nor were there a comprehensive implementing statute and regulations. This underlines the reason that this analysis focuses on the nearest thing to climate change legislation that emerged during this period - the proposed Clean Air Bill and CEPA amendments that were introduced in Parliament but not enacted. The 2007 Kyoto Protocol Implementation Act, as noted above, was at a high level of generality and was not used for regulatory implementation. No further legislative action occurred until the 2011 proposal for coal-fired electricity generation regulations.

57 Nevertheless there would be potential authority and fairness issues: see A. Lucas and O. Daudu, "Disputes and Dispute Resolution in the Offsets System" (March, 2006) BIOCAP Canada Research Integration Synthesis Paper http://www.biocap.ca/rif/report/Lucas_A.pdf. 


\section{PROPOSED COAL-FIRED ELECTRICITY GENERATION REGULATIONS}

Coal-fired generation of electricity generation regulations under CEPA, section 93(1) and 330(3.2) were proposed in August 2011.58

The performance standard would be 375 tonnes of $\mathrm{CO}_{2}$ per gigawatt hour of electricity produced. This emissions intensity standard is based on emissions that would be produced by electricity generation using natural gas combined-cycle technology.

The expectation is that these regulations will come into force in 2013, with these central performance standard requirements in effect in $2015 .{ }^{59}$ However, generators can apply for a temporary deferral up to 2025 of application of the performance standard to generation units if they agree to implement carbon capture and storage. ${ }^{60}$ Where existing generating units capture at least 30 percent of $\mathrm{CO}_{2}$ emissions for five years, an 18-month deferral for old units is available. ${ }^{61}$ There is even recognition of the expiry of power purchase agreements in determining the "useful life" of generating facilities. ${ }^{62}$ Further adjustments recognize the potential deferral of performance standards in emergency circumstances.

It is apparent that a central objective is the forced decommissioning of old generation units during a transition toward less emission-intensive natural gas-fired or renewable energy generation. The objective is emissions reduction of $65 \mathrm{Mt}$, approximately 25 percent of Canada's target of 17 percent below 2005 levels by $2020 .^{63}$ At the same time the intention is to encourage investment in less emissions-intensive electricity generation, provide predictability in planning for large capital investments, avoid stranded generation assets and limit costs through incremental action. ${ }^{64}$

In the next part we assess the constitutionality of the amended Clean Air Bill outlined above. This is done in the bill's context that includes the notice of intent ${ }^{65}$ that preceded the bill's introduction, the subsequent Turning the Corner ${ }^{66}$ Action Plan with the Regulatory Framework for Air Emissions ${ }^{67}$ and the more specific Regulatory Framework for Industrial Greenhouse Gas Emissions. ${ }^{68}$ Finally, we will assess in a preliminary way, the constitutionality of the proposed coal-fired electricity generation regulations. ${ }^{69}$

\footnotetext{
58 Proposed coal-fired electricity generationrRegulations, supra note 2.

59 Ibid., s. 28.

60 Ibid., s. 8.

61 Ibid., s. 13.

62 Ibid., definition of "useful life" in respect of a unit.

63 Notice-proposed coal-fired electricity generation regulations, supra note 2, Regulatory Impact Analysis at 3.

64 Ibid., pp. 3-4.

65 Supra note 15.

66 Supra note 23.

67 Supra note 24.

68 Supra note 49.

69 Supra note 58.
} 


\section{Constitutional Analysis}

\section{A. THE ANALYTICAL APPROACH}

Initially, we can readily identify heads of federal legislative power, under section 91 of the Constitution Act, 1867, that may potentially support the amended Clean Air Bill. ${ }^{70}$ This is a preliminary step - an outline of potential federal subject areas. These heads of power include: the federal taxation power (s.91(3)), criminal law (s.91(27)), regulation of trade and commerce (s.91(2)), and the national concern aspect of the residual peace order and good government (POGG) power. Other commentators add the emergency power under POGG. ${ }^{71}$

Analytically, the identification of potentially relevant heads of power involves making a preliminary assessment. The next step is to put the potential powers aside, notionally blinding oneself to the potential powers identified ${ }^{72}$ and turn full attention to the characterization of the legislation. Normally, judges don't even mention this preliminary consideration of heads of power. They simply recite the constitutional questions, if specified, or review the constitutional positions of the parties. Then they go directly to the act or regulation in question and its legislative context. ${ }^{73}$

The court asks, what is the "pith and substance," "dominant purpose," "true character" or "dominant or most important characteristic" of the legislation. ${ }^{74}$ It considers both the purpose and the effects of the act or regulations and the specific provisions challenged. ${ }^{75}$ When the court has reached a conclusion on pith and substance, the final step is to classify the subject matter to the appropriate head of legislative power. This usually involves interpretation to determine the scope of potentially relevant powers.

\section{B. CHARACTERIZING THE AMENDED CLEAN AIR BILL}

\section{Purpose}

On one level, the purpose of the amended Clean Air Bill seems obvious. It deals with the risks to human health and the environment caused by air pollution and GHGs. The preamble added by the Legislative Committee on Bill C-30 points to this. The preamble also recognizes the international dimension of these risks and Canada's obligations under the Framework Convention on Climate Change and the Kyoto Protocol. However, risks may additionally be to "the environment and the economy."

\footnotetext{
70 Supra note 22.

71 Hsu \& Elliot, supra note 47 at paras. 75-79.

72 Albert Able, "The Neglected Logic of 91 and 92" (1969) 19 U.Tor.L.J. 487.

73 [1997] 3 S.C.R. 213 [Hydro Quebec] Sometimes judges slide prematurely into analysis of the scope of constitutional powers identified, as in R. v. Hydro Quebec, [1997] 3 S.C.R. 213, where the majority focused on the criminal law power at para 108-118; Reference Re: Firearms Act (Can.), [2000] 1 S.C.R. 783 [Firearms Reference] at para 15.

74 Hydro Quebec (majority), ibid. at para 113; Firearms Reference, ibid. at para 16.

75 Reference re: Assisted Human Reproduction Act, 2010 SCC 61.

76 Amended Clean Air Bill, supra note 22.
} 
these preambular statements were in the bill at first reading. Does the added preamble suggest an emphasis of purpose by the legislators; or does it indicate relative weakness or uncertainty of purpose when the bill was introduced? This latter view is not implausible when it is remembered that the original bill took a multi-pollutant approach, addressing regulation of "air pollutants" and "greenhouse gases" in the same part, ${ }^{77}$ with no distinct part of the bill concerning GHG emissions. However, GHGs had already been assessed under Part 5 of CEPA, which concerns control of toxic substances generally, and added to the list of toxic substances under Schedule I to the act. ${ }^{78}$ Because substances in the schedule can then be the subject of detailed regulations, this is an alternative to the amended Clean Air Bill that could have been taken. It is the approach now adopted to regulate coal-fired electricity generation facilities. ${ }^{79}$ Though perhaps an equally problematic approach could have been to make GHGs the subject of regulations that establish a detailed regulatory system.

Further, despite the reference in the preamble to the Framework Convention on Climate Change and the Kyoto Protocol, the language of the bill makes it clear that these international obligations, particularly the Kyoto Protocol commitment to reduce emissions by six percent from 1990 levels by 2012, will be treated as merely aspirational. Home grown GHG emissionreduction targets are specified in the form of a "Domestic Carbon Budget," to be 20 percent less than 1990 levels by 2020,35 percent less by 2035 and 60-80 percent less by $2050{ }^{80}$

But core provisions in the Clean Air Bill do aim at GHG emission reduction. In addition to the overall domestic carbon budget ${ }^{81}$ with prescribed and decreasing totals, industrial carbon budgets, portions of the domestic budget, are established each year by the Environment Minister for carbon emitters. Criteria for industrial carbon budgets include early emissionreduction actions taken, the internal transfer of emission reductions and "fair treatment as regards [a] person's average economic growth compared with the applicable average sectoral growth." 82

Certain economic sectors are specified, with the Minister empowered to designate "Large Industrial Emitters:"

a) in the electricity generation sector that uses fossil fuels

b) upstream oil and gas operators (excluding petroleum refiners and natural gas distributors), and

c) energy intensive industries including "persons that use energy derived from fossil fuels. ${ }^{83}$

For each of these subsectors, the Minister is authorized to set a "sectoral carbon budget." 84

\footnotetext{
77 Ibid., s.18 adding s.103.09.

78 Government of Canada, "Order Adding Toxic Substances to Schedule 1 of the Canadian Environmental Protection Act," /SOR/2005-345, November 21, 2005, Canada Gazette Part II, Vol. 139, No. 24, 21 November, 2005 [CEPA SO2 Scheduling Order].

79 Proposed coal-fired electricity generation regulations, supra note 2.

${ }^{80}$ Ibid., s.103.2.

81 Ibid., s.103.2.

82 Ibid., s.103(3)(c).

83 Ibid., s.103.05.

84 Ibid., s.103.05(1).
} 
Offences added by the amended Clean Air Bill include s.103.11, concerning release of a GHG in contravention of a regulation made under s.103.09 or an order requiring a report and remedial measures under s103.1. CEPA's main offence provision is also amended ${ }^{85}$ to include an offence of failing to remit a required tradable emission unit to the Minister. Already included in CEPA are offences concerning contravention of the act, the regulations, or any obligation, prohibition or order under the act or the regulations. ${ }^{86}$

All of these provisions suggest that the intended purpose of the bill is GHG emission reduction. This is to be accomplished through a complex regulatory scheme. The scheme is founded on establishment of general and individual emission "budgets" - emission limits. Failure to meet these individual budgets is the subject of offences tailored to the regulatory scheme, including failure to remit tradable emission units required to meet individual emission budgets. These tradable units would be created under the GHG emission trading system that the Governor-in-Council is authorized under s.94.1(1)(a) to establish by regulation. Tradable units could also be created under the domestic offset system, previously the subject of a major government report, that the Governor-in-Council would set up by regulation under s.94.1(1)(b). Finally, emission units under foreign or international systems might also be used to meet emission budgets should the Governor-in-Council, under s.94.1(1)(c), make regulations to "link" with those systems. So while the detail of these emission trading systems is speculative, depending on the making of complex regulations, the objective of creating these market-based mechanisms, to be part of the overall GHG emissions-reduction scheme, is clear.

However it must be kept in mind that the scheme, with its core emission limits and market mechanisms, is targeted. While GHGs are produced by a variety of specific sources and industrial sectors, only certain sectors are specifically mentioned in the bill. ${ }^{87}$ These major sectors are fossil fuel-based electricity generation and upstream oil and gas. Both sectors would appear to be included in the third category mentioned, namely "energy intensive industries ..." 88 This suggests that the purpose of GHG emission reduction is not general, but rather aimed at certain emission-producing sectors and more specifically at the category of large industrial emitters within those sectors.

If focus is placed on the emissions trading system that centres on large industrial emitters, a more nuanced view of Parliament's purpose emerges. This is consistent with the necessity, underlined by four members of the Supreme Court of Canada in the Assisted Human Reproduction Act Reference, to identify the pith and substance of impugned provisions as precisely as possible. ${ }^{89}$ Their concern was that vague and general pith and substance characterizations could lead to confusion and dilution of established constitutional doctrines and to erosion of the scope of provincial powers through operation of the federal paramountcy

\footnotetext{
85 CEPA s.27.

86 Ibid., s.272(2).

87 The fossil fuel electricity generation and upstream oil and gas sectors, along with base metal smelters, iron and steel cement, forest producers and chemicals production account for only 47 percent of Canada's GHG emissions: Notice of Intent, supra note 15 at 15.

88 Amended Clean Air Bill, supra note 22, s.14.1 adding s.103.05(1)(c).

892010 SCC 61 at para 190, per Justices Lebel and Deschamps. (Justices Abella and Rothstein concurring). While not a majority, these judges were part of a 5-4 majority (the fifth judge simply adopted a more robust pith and substance characterization). Their theory and analysis represents strong persuasive authority.
} 
doctrine..$^{90}$ They noted, for example, that a finding that a provision is in pith and substance in relation to health or to the environment would be problematic and concluded that it is necessary to undertake further analysis to determine what aspect of the field in question is being addressed..$^{91}$

\section{Effects}

In particular, pith and substance identification requires, as the Supreme Court noted in the Firearms Reference, an assessment of the effects of the impugned provisions. ${ }^{92}$ This inquiry is directed to actual impact of the provisions on Canadians.

Here, that inquiry shows that specific industrial sectors are targeted - energy production and industrial operations located in provinces. ${ }^{93}$ These are classic local works and undertakings. ${ }^{94}$ Furthermore, the offset system paper reveals that the proposed system will recognize emissions offsets created primarily through forestry and land use change actions within provinces, including on provincial Crown lands. ${ }^{95}$ This leads to a more restricted pith and substance characterization for sections 94.1 and 103.2 that authorize creation of emissions trading and offset systems, namely regulation of energy, production, industrial operations and land use activities to reduce GHG emissions from those operations and activities.

These effects become even clearer if the technique chosen is based on reduction of emissions intensity (GHG emissions as a function of production), as was the case for the Clean Air Bill as originally introduced. ${ }^{96}$ This would take the decisions necessary to establish emissions limits down to the level of plant operations and production processes. Corporate planning and plant and facility operations would be directly affected by this kind of regulation. Focus sharpens when regulations envisioned to create a technology investment fund are considered. The idea is that industry could contribute toward development of new technologies for emissions reduction and receive credits that could be used to meet emission limits. Furthermore, the notice of intent ${ }^{97}$ specifically mentioned carbon capture and storage, a technology particularly relevant to the energy sector, that has been the subject of industry and government research investment.

The result is that while those provisions of the amended Clean Air Bill that authorize establishment of GHG emission limits through carbon budgets may in a broad sense be in pith and substance concerned with GHG emission reduction, closer examination suggests that they concern the GHG emissions element of the management and operation of specific categories of industrial facilities within provinces. This alternative characterization is particularly plausible for the provisions to establish a system for emission credit creation and trading. The pith and substance of the latter provisions would be regulation of industrial operations in particular sectors.

\footnotetext{
90 Ibid.

91 Ibid.

92 Reference Re Firearms Act (Can) 2000 SCC 31 at para 18 [Firearms Reference].

93 Amended Clean Air Bill, supra note 22 adding s.103.05.

94 As this term is used in s.92(10) of the Constitution Act, 1867.

95 Minister of the Environment, Canada's Offset System for Greenhouse Gases, supra note 53; amended Clean Air Bill, supra note 22, s. 10, adding s.94.1(1)(b).

96 Amended Clean Air Bill, supra note 22, s.18, adding s.103.09.

97 Notice of Intent, supra note 15 at 3360.
} 


\section{CLASSIFICATION TO HEADS OF POWER}

What are the heads of federal legislative power to which the proposed regulations can be classified? The primary choices are: criminal law, peace, order and good government (POGG) and possibly regulation of trade and commerce. ${ }^{98}$ Each of these is discussed below. The classification to a federal head of power involves matching the legislation's dominant purpose with an enumerated power of the constitution. POGG is relied upon only if there is no applicable enumerated power. ${ }^{99}$

At the classification stage of the federalism analysis, there is no authoritative template or set of criteria. Determination of which head of legislative power can best accommodate a particular law has been described as "not an exact science." ${ }^{\prime 00}$ The formal question is what head of power the law in its substance is "in relation to." 101 But it may be inferred that courts are guided by functional criteria such as relative efficiency in addressing the problem. ${ }^{102}$ This may be expressed as which government is best situated to deal with the issues identified in the characterization exercise. Whether and the extent to which the enacting government was sensitive to the need for cooperation and coordination may be considered for this purpose..$^{103}$ Subsidiarity - the idea that action should be taken by the government closest to affected citizens - is also a relevant constitutional principle. ${ }^{104}$

History and tradition may be significant factors. This can be seen in the Firearms Reference where the Supreme Court's conclusion that "gun control has traditionally been considered valid criminal law ..."105 proved important. The basis given for this was the obvious link to public safety. Analogous is Justice La Forest's conclusion in R. v. Hydro Quebec that stewardship of the environment has emerged as a fundamental value of Canadian society that is consequently appropriate for criminal law protection. ${ }^{106}$

Democratic values such as accountability, diversity and responsiveness are also relevant. ${ }^{107}$ However, in the Firearms Reference the Supreme Court firmly rejected application of the Canadian Charter of Rights and Freedoms Section 1 justification analysis. The court was clear that a balancing approach based on rationality and proportionality criteria would not be helpful in determining the appropriate balance between the federal and provincial heads of power. ${ }^{108}$

98 Should the government choose to implement a carbon tax, it would trigger s. 91(3) of the Constitution Act, 1867 to legislate in relation to "The Raising of Money by Any Mode or System of Taxation."

99 R. v. Hydro Quebec, supra note 73 at para $116,117$.

${ }^{100}$ Firearms Reference, supra note 73 at para 26.

${ }^{101} \mathrm{Ibid}$. at para 25.

${ }^{102}$ Hydro Quebec, supra note 73 at para 154. Justice La Forest referred to efficiency in the sense of not preventing Parliament from exercising leadership in protecting environmental values - a role "expected of it by the international community."

${ }^{103} \mathrm{Ibid}$. at para 153 . The argument that equivalency provision s are indicative of the essentially regulatory nature of federal legislation (this pointing to provincial heads of power) was rejected by Chief Justice MacLachlin in the Assisted Human Reproduction Reference, supra note 89 at para 1153.

104 Assisted Human Reproduction Act Reference, supra note 89 at para 183.

${ }^{105}$ Firearms Reference, supra note 73 at para 33.

${ }^{106}$ Hydro Quebec, supra note 73 at para 127.

${ }^{107}$ Peter W. Hogg, Constitutional Law of Canada, 5th Ed. Supplemented Vol. (Toronto: Carswell) [Hogg, Constitutional Law] at $15-50$.

${ }^{108}$ Firearms Reference, supra note 73 at para 48. 
Classification analysis involves, as shown in Hydro Quebec, interpretation of the scope and content of those legislative powers that appear on an initial scan to be most relevant. As La Forest stated in Hydro Quebec: ${ }^{109}$

...I have gone on at this length to demonstrate the simple proposition that the validity of a legislative provision (including one relating to environmental protection) must be tested against the specific characteristics of the head of power under which it is proposed to justify it. For each constitutional head of power has its own particular characteristics and raises concerns peculiar to itself in assessing it in the balance of Canadian federalism...

\section{i. Regulation of Trade and Commerce}

Notwithstanding the emissions trading element of the amended Clean Air Bill's overall scheme, jurisdiction under the federal trade and commerce power is not a good fit. Not even the intention to link the domestic emissions trading scheme to international instruments under the Kyoto Protocol and potentially to international emissions credit markets is likely to find support under this federal class of subjects. ${ }^{110}$

The federal power over trade and commerce has been narrowly interpreted. The Privy Council, in Citizens Insurance v. Parsons restricted the federal power to two branches: ${ }^{111}$ (i) interprovincial and international trade and commerce; and (ii) general trade and commerce affecting the whole country. The policy behind this decision appears to be limitation of the federal power in order to preserve the autonomy of the provinces. More recently, there has been a pulling back from this position as Canada's economy developed. ${ }^{1 / 2}$

Simply creating a trading mechanism for air emissions is not likely to be enough to uphold the legislation under the first branch. Significantly, the "goods" in the trade concerned are constructs created under specific environmental legislation that are instrumental in a scheme of GHG emission reduction. One commentator suggests that the federal government can rely on the Supreme Court's decision in Re Agricultural Products Marketing Act. ${ }^{113}$ He states that an emissions trading scheme contains parallels, particularly the setting of national quotas of production, to the regime in that case. Hogg disagrees. He thinks that Re Agricultural Products Marketing Act is very fact-specific. ${ }^{114}$ In particular the marketing scheme had been agreed to by all provincial governments and both provincial and federal governments had enacted regulations to implement the plan. Even if the provinces and federal government were to reach a similar agreement, the nature of the trade - instruments for GHG emission reduction makes federal jurisdiction under the first branch of the trade and commerce power unlikely.

\footnotetext{
${ }^{109}$ Hydro Quebec, supra note 73 at para 117.

110 Amended Clean Air Bill, supra note 22, s.14.1 adding s. 94.1(1)(c).

111 (1881), 7 App. Cas. 96 [Parsons].

112 Brian Morgan, "The Trade and Commerce Power," in Joseph Magnet (Ed.), Constitutional Law of Canada, Vol. 1 (Edmonton: Juriliber Limited) 476 at 486.

113 Joesph F. Castrilli "Legal Authority for Emissions Trading in Canada," in Elizabeth Atkinson, ed. The Legislative Authority to Implement a Domestic Emissions Trading System, January 1999 (Ottawa: National Round Table on the Environment and the Economy) at Appendix 1, 15 citing the Reference Re Agricultural Products Marketing Act, [1978] 2. S.C.R. 1198.

${ }^{114}$ Hogg, Constitutional Law, supra note 107 at 20-7 - 20-8.
} 
A more interesting question is whether the proposed act can be upheld under the second branch of Parsons: general trade. The challenge is to balance the general trade and commerce power of the federal government with the provincial power over property and civil rights. ${ }^{115}$ The legislation must meet five criteria in order to be classified as a valid exercise of the general trade and commerce power: ${ }^{116}$

- the impugned legislation must be part of a general regulatory scheme;

- the scheme must be monitored by the continuing oversight of a regulatory agency;

- the legislation must be concerned with trade as a whole rather than with a particular industry;

- the legislation should be of a nature that the provinces jointly or severally would be constitutionally incapable of enacting; and

- the failure to include one or more provinces or localities in a legislative scheme would jeopardize the successful operation of the scheme in other parts of the country.

The criteria are not exhaustive and the absence or presence of any one of them is not necessarily determinative.

The first criterion, the presence of a regulatory scheme, is a fundamental characteristic of valid trade and commerce legislation. ${ }^{117}$ It is clear that the scheme intended under the amended Clean Air Bill would be a complex regulatory scheme including required and prohibited conduct, a mechanism to establish an emissions credit "market," investigatory procedures, public regulators, and remedial and punitive provisions. It is also clear that the scheme would be under the constant oversight of some type of regulatory agency. ${ }^{118}$ The third criterion is whether the scheme is national. The scheme would apply to all of Canada and to a variety of individuals and corporate entities - but not to all industrial sectors. Certain sectors, particularly oil and gas and electricity generation, would be targeted. However, GHG emissions are not a purely local issue, but rather a national and international one. Provinces can enact GHG emissions reduction legislation; Alberta, for example, has done so. ${ }^{119}$ But it is unclear whether climate change legislation in a small jurisdiction, particularly emissions trading schemes limited to provinces, can be successful. Similarly, it is not clear whether the failure of one or several provinces to act would jeopardize the efforts of the remaining provinces. There are deep divisions between provinces - particularly between hydrocarbon energy producers and hydroelectricity reliant provinces - that are likely to make broad interprovincial agreements difficult.

\footnotetext{
${ }^{115}$ General Motors of Canada v. City National Leasing, [1989] 1 S.C.R. 641 at 659 [General Motors].

${ }^{116} \mathrm{Ibid}$. at 677.

117 Ibid. at 667.

${ }^{118}$ In the amended Clean Air Bill, supra note 22 the Minister of the Environment (Environment Canada) is authorized to exercise a range of specific regulatory powers.

${ }^{119}$ N. Bankes and A. Lucas, supra note 1.
} 
There is a limit to how much the federal government can intrude incidentally into provincial jurisdiction. In Calioil v. Canada, the Supreme Court upheld a law that limited the transportation or sale of imported oil west of the Ottawa Valley. ${ }^{120}$ The legislation was determined to be an extra-provincial marketing scheme designed to protect Alberta's oil industry. Although the law had a direct impact on trade within Ontario, it was incidental. It was "an integral part of the control of imports in the furtherance of an extra-provincial trade policy.", 121

The conclusion, whether the pith and substance is GHG emission reduction or even (concerning the emissions trading and technology fund elements) if it is regulation of GHG emissions by energy and industrial operations, is that the bill is unlikely to be valid under the trade and commerce power. ${ }^{122}$

\section{ii. Peace Order and Good Government}

The federal power under POGG is essentially residual. It is limited to matters not coming within those powers assigned exclusively to the provincial legislatures. ${ }^{123}$ Early guidance in the Local Prohibition Reference opinion was that this power "ought to be strictly confined to such matters as are unquestionably of Canadian interest and importance, and ought not to encroach upon provincial legislation with respect to any of the classes enumerated in s. $92 ., " 24$

Perhaps the most significant discussion of the national concern doctrine is found in R. v. Crown Zellerbach ${ }^{125}$ in which the Supreme Court's approach suggested a reluctance to make frequent use of this branch of POGG. This reluctance was reinforced in R. v. Hydro Quebec. ${ }^{126}$ The problem is that assigning a matter to POGG impacts the fundamental balance of power between the provinces and the federal government. Consequently, potential classification to potentially appropriate enumerated heads of power should be tested before resort is had to POGG. ${ }^{127}$

The test to determine whether a matter falls within the national concern branch, under which a subject that might otherwise fall within a provincial head of power may be classified under POGG, is as follows:

- Is it a new matter that did not exist at Confederation or an old matter that has become one of national concern?

- To qualify as a matter of national concern, the matter must have a singleness, distinctiveness and indivisibility that clearly distinguishes it from matters of provincial concern.

${ }^{120}$ [1971] S.C.R. 543 [Caloil].

${ }^{121} \mathrm{Ibid}$, at 552 .

${ }^{122}$ Stewart Elgie, in "Kyoto, the Constitution and Carbon Trading: Waking a Sleeping BNA Bear," (2007). Review of Constitutional Studies, 67 at 110-120, argues that the emissions trading propositions of the Kyoto Protocol Implementation Act, S.C. 2007, c. 30 can be upheld under the trade and commerce power. Central to his analysis is the idea that provinces are functionally unable to regulate matter that by its nature requires federal regulation.

${ }^{123}$ S. 91, Constitution Act.

${ }^{124}$ Ontario (A.G.) v. Canada (A.G.), [1896] A.C. 348 (P.C.) [Local Prohibition Reference] at 360-361.

${ }^{125}$ R. v. Crown Zellerbach Canada Ltd. [1988] 1 SCR 401 [Crown Zellerbach].

${ }^{126}$ Hydro Quebec, supra note 73 at para 115 and Crown Zellerbach, supra at para 62.

${ }^{127}$ Hydro Quebec, ibid. at para 116. 
- Is the scale of impact on provincial jurisdiction reconcilable with the fundamental distribution of legislative power?

- The above questions are modified with an evaluation of the effect on extra-provincial interests of a provincial failure to deal effectively with the intra-provincial aspects of the matter. $^{128}$

The Supreme Court has held consistently that the environment is a matter of shared jurisdiction. ${ }^{129}$ Even so, the Court, in a 5-4 split, upheld under POGG federal legislation dealing with dumping in marine waters. The majority found the test for singleness, distinctiveness and indivisibility was met by limiting the application to marine waters. The minority disagreed, concluding that the power under POGG is broad and could, on the majority's view, conceivably extend deep into provincial jurisdiction including regulation of land-based air contaminants that fall into marine waters. The point is that it is rarely a clear and simple matter to validate legislation under POGG.

The matter of air pollution and even of climate change is not new. Air pollution, including the release of GHGs into the atmosphere, has been occurring as long as humans have burned anything for heat. However, it could be argued that the emergent critical nature of climate change and its consequences transformed this issue into one of national concern.

Yet the amended Clean Air Bill does not formulate the matter in a way that meets the test for singleness, distinctiveness and indivisibility. It deals with GHG emissions in parts 5.1 and 5.2. The problem is that a wide range of modern human activity produces GHG emissions so that it is difficult to discern the limits of the provisions. It is a case of the legislation defining the regulated substances with some precision, but the substances themselves being so pervasive that the scope and impact is rendered uncertain. Hsu and Elliot see the matter as both federal and provincial. ${ }^{130}$

The lack of singleness would lead to extensive intrusion into provincial powers. The scale of impact on provinces, particularly energy producing provinces such as Alberta, faced with the provisions targeting energy producers, would be serious. Moreover, classification of a broadly conceived climate change or even a GHG emission subject as a POGG matter could prevent provincial regulation on a local scale. ${ }^{13 l}$ This may be a subject to which the principle of subsidiarity - the idea that the legislature closest to particular citizen concerns is in the best position to take action - is particularly applicable. Four Supreme Court judges in Reference Re: Assisted Human Reproduction Act recognized that the Constitution Act's division of power is "largely consistent with the principle of subsidiarity." 132

Commentators do not agree on the use of this power. Hogg states that there is "no doubt" that the federal government could enact environmental protection legislation under this branch. ${ }^{133}$

\footnotetext{
${ }^{128}$ Crown Zellerbach, supra note 125 at para 62.

${ }^{129}$ Ibid. at para 59.

${ }^{130}$ Supra note 47 at para 74.

${ }^{131}$ Hydro Quebec, supra note 73 at para 115.

${ }^{132}$ Assisted Human Reproduction Act Reference, supra note 89 at para 183.

${ }^{133}$ Hogg, "A Question of Parliamentary Power," supra note 10 at 3.
} 
Hsu and Elliot disagree. They suggest that the matter of climate change is not single, distinctive and indivisible and that the scale of impact into provincial jurisdiction would be too extreme. ${ }^{134}$ Underlying these differences may be whether the provinces are unable to deal with the problem of climate change and GHG emissions. Hogg suggests that the provincial inability test is a critical factor: ${ }^{135}$

The most important element of national concern is a need for one national law which cannot realistically be satisfied by cooperative provincial action because failure of one province to cooperate would carry with it adverse consequences for the residents of other provinces. A subject-matter of legislation which has this characteristic has the necessary national concern to justify invocation of the p.o.g.g. power.

There is an argument that the seriousness of climate change and the inability of the provinces to reach an agreement brings the subject matter into the domain of the federal government.

However, it is the scale of the impact on provincial jurisdiction that seems most telling against POGG classification of the amended Clean Air Bill. As framed, the bill would cut deeply into core provincial jurisdiction in relation to regulation of industrial and energy facilities - "local works and undertakings." The scheme reaches to the level of facility technology and operations - matters of property in the province. In these circumstances, the Supreme Court's expressed reluctance to sweep broad environmental matters under federal POGG jurisdiction is significant. The court's approach to POGG classification of the toxics regulation provisions of CEPA, part of the very statute the Clean Air Bill amends, is apparent in Hydro Quebec. As articulated by Justice La Forest in his Crown Zellerbach minority judgment, and applied in writing for the Hydro Quebec majority, the court should, before consideration of POGG, first focus on potentially relevant enumerated heads of federal power and pay close attention to the "ambit and contours" of those powers. ${ }^{136}$ In Hydro Quebec, it was the criminal law power that was held to support the provisions in question.

\section{iii. Criminal Law}

\section{CHARACTER OF CRIMINAL LAW}

To be in relation to criminal law, a law must have (i) a valid criminal purpose; (ii) the backing of a prohibition and; (iii) a penalty. ${ }^{137}$

Some matters, such as gun control ${ }^{138}$ which address risks to public safety, have "traditionally" been considered to be valid criminal law. Though the position is not as clear for environmental harm, the Supreme Court majority in Hydro Quebec stated that "stewardship of the environment is a fundamental value of our society so that Parliament may use its criminal law power to underline that value". Because this is surprisingly broad and sweeping language, it is useful to place these words in the context of a longer quotation. The court quoted Justice

\footnotetext{
${ }^{134}$ Supra note 47 at para 74.

${ }^{135}$ Hogg, Constitutional Law, supra note 107, 17-16.

${ }^{136}$ Crown Zellerbach, supra note 125 at para 117. In Hydro Quebec, the majority judges did not consider it necessary to determine whether the legislation fell within federal jurisdiction to legislate for the peace, order and good government of Canada.

${ }^{137}$ Firearms Reference, supra note 73 at para 31.

${ }^{138}$ Ibid
} 
Gonthier speaking for the majority in Ontario v. Canadian Pacific Ltd., where he cited the Law Reform Commission of Canada's report, 'Recodifying the Criminal Law,' in which the Commission proposed a new federal environmental crime to address "widespread, cumulative and chronic" effects of what it described as "industrial pollution." From this, the Hydro Quebec majority concluded: ${ }^{.139}$

What the foregoing underlines is what I referred to at the outset, that the protection of the environment is a major challenge of our time. It is an international problem, one that requires action by governments at all levels. And, as is stated in the preamble to the Act under review, "Canada must be able to fulfill its international obligations in respect of the environment". I am confident that Canada can fulfill its international obligations, in so far as the toxic substances sought to be prohibited from entering into the environment under the Act are concerned, by use of the criminal law power. The purpose of the criminal law is to underline and protect our fundamental values. While many environmental issues could be criminally sanctioned in terms of protection of human life or health, I cannot accept that the criminal law is limited to that because "certain forms and degrees of environmental pollution can directly or indirectly, sooner or later, seriously harm or endanger human life and human health", as the paper approvingly cited by Gonthier J. in Ontario v. Canadian Pacific, supra, observes. But the stage at which this may be discovered is not easy to discern, and I agree with that paper that the stewardship of the environment is a fundamental value of our society and that Parliament may use its criminal law power to underline that value. The criminal law must be able to keep pace with and protect our emerging values.

On this basis, the Supreme Court in Hydro Quebec upheld the CEPA provisions that govern the assessment of substances to determine toxicity, the listing of substances found to be toxic in a schedule to the act and the regulations with criminal penalties governing the release of those toxic substances into the environment. GHGs were subsequently assessed in this way and added to the schedule of toxic substances. This is what led Hogg to conclude that federal legislation based on the Regulatory Framework for Air Emissions, released after the amended Clear Air Bill died on the order paper, which would prescribe emissions limits for GHGs, would be "a perfectly safe exercise of Parliament's criminal law power." 140

The purpose of the amended Clean Air Bill is to reduce air emissions in order to protect the environment and the health of all Canadians - particularly the most vulnerable members of society. ${ }^{141}$ The bill adds the offence of failure to remit a tradable unit. ${ }^{142}$ Following conviction on indictment, the penalty can be a fine and/or imprisonment for a term not to exceed three years. On summary conviction, the penalty can be a fine and/or imprisonment for a term of not more than six months. CEPA already includes an offence of failing to comply with any provision of the act or regulations and with any orders made under the statute or the regulations.

\footnotetext{
${ }^{139}$ Hydro Quebec, supra note 73 at para 127.

${ }^{140}$ P. Hogg, “A Question of Parliamentary Power", supra note 10 at 6.

${ }^{141}$ S.103.01. The purpose of the Clean Air Bill Amendment is similar. Section 103.06 reads, "The purpose of this Part is to protect the health of Canadians and improve the environment by addressing the anthropogenic deterioration of air quality."

${ }^{142}$ Ibid., s.272(2.1). The amended Clean Air Bill has the same penalty provisions as the original Bill.
} 
A factor that may be significant in assessing criminal law support for the amended Clean Air Bill is that the original bill introduced in Parliament included a new CEPA Part 5.1 headed "Clean Air," that addressed both air pollutants as defined, and GHGs. Thus, GHGs were no longer to be listed in the CEPA Toxic Substances Schedule and as such regulated under Part 5, the CEPA provisions that were upheld under the criminal law power in Hydro Quebec. Part 5.1 commenced with a purpose statement, namely "to promote the reduction of air pollution and to promote air quality in order to protect the environment and the health of all Canadians ..."143 The objective appears to be to focus on the core environmental values recognized by the Supreme Court in Hydro Quebec. But addressing GHGs indirectly, as part of a broader class of air contaminants that includes "air pollutants," could be taken as indicating at least uncertainty about the urgency of protecting Canadians from the harm caused by GHGs. In introducing the original Clean Air Bill, the Environment Minister did not single out GHGs (from "air pollutants") as a significant concern.

However, all of this changed with the Parliamentary Committee's review of the bill and the amendments that created the amended Clean Air Bill that is the subject of this analysis. The preambular statements concerning climate change and the international treaties cited above were added, along with the specific provisions for regulation of GHGs, including national and individual carbon budget emission limits, and authority to create a GHG emissions trading system.

So, while the amended bill would increase focus on GHGs, it still would not bring GHGs under CEPA Part 5, the provisions upheld in Hydro Quebec. The about-face is troubling and indicates uncertainty about whether GHGs are substances that belong in the toxics assessment and regulation process under Part 5 of CEPA.

All of this suggests that while there is a plausible basis for criminal law jurisdiction to support the amended Clean Air Bill, provincial powers over local works and undertakings and property and civil rights may also be engaged, particularly when effects on industrial and energy facilities and operations within provinces are considered. There is little doubt that there can be incidental overlap or overflow of federal criminal law power into provincial subjects. ${ }^{144}$ But the insistence of four judges in the Assisted Reproduction Act Reference that the scope of the criminal law power must be assessed to prevent incursion on provincial powers is a strong indication that the nature and extent of overflow must be carefully considered with the subsidiarity principle (power should be exercised by the government closest to the contested subject matter) in mind. ${ }^{145}$

Characterization of the pith and substance as regulation of GHG emissions by persons and corporations - particularly by certain energy sectors - would point to the amended Clean Air Bill being not essentially criminal, but regulatory. Appropriate prohibitions within the federal criminal law power have been described as "discrete."146 But the carbon budget limits system, along with the emission-credit trading system with credits tendered to meet carbon budget limits, is anything but discrete. The prohibition is not directed against specified emissions, but against emissions that cannot, in effect, be paid for by tendering the required quantity of emission credits.

\footnotetext{
143 s.18, adding s.103.01.

144 Assisted Reproduction Act Reference, supra note 89 at para 190. Chief Justice McLachlin, at para 32, spoke of either level of government being permitted to enact laws that have "substantial impact on matters outside its jurisdiction."

${ }^{145}$ Ibid., para 183.

${ }^{146}$ Hydro Quebec, supra note 73 at para 128.
} 
The source and therefore the fundamental nature of these nominally fungible credits varies considerably. Credits are generated by reducing emissions below individual emission budgets. Other credits (offsets) are created by sequestration of $\mathrm{CO}_{2}$ in agricultural and geological sinks. The amended Clean Air Bill proposed a regulatory system for issuance of these offset credits. ${ }^{147}$ Still other credits could result from GHG reductions in other countries. ${ }^{148}$ Even credits based on investment in GHG-reduction technology could be used. ${ }^{149}$ All of these various types of credit could be acquired by purchase or trade. The prohibition would establish limits or standards on a different basis for different segments of industry. There were also fiscal elements of this GHG emission reduction regime, including the federal government's $\$ 15$ per tonne cap on the cost of emission credits. ${ }^{150}$

All of this adds up to a complex and comprehensive regulatory scheme. The summary in the amended Clean Air Bill stated that the legislation "enables the Government of Canada to regulate air pollutants and greenhouse gases, including establishing emission-trading programs...". The notice of intent referred to the federal government's intention to "develop and implement regulatory measures...". 151

\section{UNDUE INTRUSION INTO PROVINCIAL POWERS}

The Supreme Court of Canada has often stated that the only limitation on the criminal law power is that it cannot be used colourably. ${ }^{152}$ But if colourability involves improper motives or a kind of constitutional aggression through federal occupation of provincial jurisdiction under the guise of criminal legislation, this amounts to a rather narrow limitation. More important, such a concept would be extremely difficult to apply in a reasoned and coherent manner. Perhaps for this reason, in the Firearms Reference the Supreme Court openly addressed undue intrusion into provincial powers. It considered colourability in the sense of improper purpose or bad faith to be part of the question of whether the federal government is using the criminal law power to enter a new field and thus expand its powers relative to those of the provinces. ${ }^{153}$

This intrusion factor appears to be analogous to the scale of impact on the provincial powers criterion $^{154}$ that is part of the POGG national concern analysis. It permits the court to avoid speculation about Parliament's motives, a question that goes beyond legislative intent in the usual sense, and focus on relevant functional considerations. These include hindrance of provincial ability to regulate a matter, preemption of provincial choice whether or not to legislate, effects on established provincial subjects and federal entry into a new field. ${ }^{155}$

\footnotetext{
${ }^{147}$ Canada's Offset System, supra note 43.

${ }^{148}$ Amended Clean Air Bill, supra note 22, s.14.1 adding s.9.4.1(i)(c).

${ }^{149}$ Notice of Intent, supra note 15 at 14.

${ }^{150}$ Subsequently proposed in the Regulatory Framework for Air Emissions, supra note 24 at 12-13.

${ }^{151}$ Notice of Intent, supra note 15 at 3352.

${ }^{152}$ Hydro Quebec, supra note 73 at para 121 and authorities cited.

${ }^{153}$ Firearms Reference, supra note 73 at para 53.

154 "For a matter to qualify as a matter of national concern in either sense it must have a singleness, distinctiveness and indivisibility that clearly distinguishes it from matters of provincial concern and a scale of impact on provincial jurisdiction that is reconcilable with the fundamental distribution of legislative power under the Constitution," Crown Zellerbach, supra note 125 at para 3.

${ }^{155}$ Firearms Reference, supra note 73 at paras. 50-53.
} 
Applying this intrusion test to the amended Clean Air Bill, it is not immediately clear that provinces are hindered in their ability to exercise their property and civil rights-centred jurisdiction to regulate emission of GHGs. Alberta has already enacted the Climate Change and Emissions Management Act ${ }^{156}$ mandated GHG emissions reporting, set emission targets and established a legal framework for emissions trading. ${ }^{157}$ Other provinces have proposed alternative approaches to reducing GHG emissions. ${ }^{158}$

Provincial choice of whether or not to legislate is undoubtedly affected. Future provincial climate change legislation would obviously have to take account of the federal legislation. But this is normal where jurisdiction is uncertain. Alberta did this in enacting its Climate Change and Emissions Management Act, by including provision for inter-jurisdictional agreements. ${ }^{159}$ The amended Clean Air Bill contained equivalency provisions based on federal-provincial agreements. ${ }^{160}$ Previously, the notice of intent made it clear that the federal policy involves cooperation and consultation with provinces. This is to be achieved through CEPA equivalency agreements that would leave the equivalent provincial laws as the effective instruments.

As to effects on established provincial subject matter, the provincial position is stronger. The GHG emission budgets (emission limits) contemplated by the amended Clean Air Bill and the notice of intent ${ }^{161}$ targeted the largest producers in the industrial and natural resource sectors. This is no incidental effect on provincial industrial and natural resource activities. These are core economic activities in the provinces - local works and undertakings contemplated by s.92(10) of the Constitution Act, 1867. They involve conservation and management of: nonrenewable resources (s.92A) and public lands generally (s.92(5)) and, of course, property and civil rights in the province (s.92(13)) and matters of a local or private nature (s.92(16)).

Further, these federal provisions would represent federal entry into a new field. While it is not an attempt to occupy the field of environmental regulation generally, the importance of the industrial sectors regulated and the role of this regulatory scheme in national economic transformation, present more than incidental effects on traditional provincial subjects. ${ }^{162}$ The focus in the Notice of Intent on consultation with the provinces in setting targets suggested federal concern about potential impacts on industry.

The Supreme Court has recognized that it must, in reaching a conclusion on undue intrusion, step back to assess the impact of the federal prohibitory measures on the overall balance between federal and provincial heads of power. Justice La Forest's conclusion in Hydro Quebec was that concern about the federal toxic substances assessment regime and resulting prohibition on release of PCBs, was "overstated." 163 But the broader objectives underlying the amended Clean Air Bill, namely the idea of economic transformation to achieve a less carbonintensive economy, and the economic impact on the largest industrial and energy producers,

\footnotetext{
${ }^{156}$ S.A. 2003, c. C-16.7 [CCEMA].

157 Specified Gas Reporting Regulation, Alta. Reg. 251/2004; Specified Gas Emitters Regulation, Alta. Reg. 139/2007.

${ }^{158}$ For example British Columbia has established carbon tax, Carbon Tax Act, S.B.C. 2008, c. 40.

${ }^{159}$ CCEMA, s.8.

160 Amended Clean Air Bill, supra note 22, s.103.051.

${ }^{161}$ And confirmed by the Regulatory Framework for Air Emissions, supra note 24.

162 Though criminal prohibitions can undoubtedly target economic interests: Hydro Quebec, supra note 73 at para 121 per La Forest J.

${ }^{163}$ Ibid., para 131.
} 
make undue intrusion in provincial powers at least a much more plausible argument than it was in either Hydro Quebec or the Firearms Reference. This, coupled with uncertainty about federal jurisdiction based on the peace, order and good government power, discussed above, undoubtedly prompted the CEPA equivalency agreement approach. The federal government offered upfront to use this cooperative legislative mechanism which, upon agreement, would leave the provinces in charge of the system. It chose not to hold equivalency as a bargaining chip.

\section{ANCILLARY POWERS AND OVERFLOW}

The idea of federal "ancillary" powers or "overflow" of legislative power becomes important where only certain provisions of a statute are challenged. ${ }^{164}$ This is potentially a basis for upholding the validity of the amended Clean Air Bill as criminal law. Here, we are assessing an amending bill that adds to, and to a limited extent modifies, an existing statute, the element of which concerning toxic substances was already upheld as valid criminal law in Hydro Quebec. ${ }^{165}$ Certain specific provisions of the amended Clean Air Bill that appear to create significant jurisdictional overflow require examination.

These are the provisions that authorize establishment of an emission-credit trading system based on GHG emissions and "offset" emission credits from a variety of GHG reduction activities, and provisions for a technology fund, contributions to which could also create marketable emission credits.

The analytical approach requires the court to determine whether (1) there is potential overflow into provincial powers, (2) the act (or a severable part) is valid and if so, (3) the impugned provision (or provisions) is sufficiently integrated with the overall scheme of the act. ${ }^{166}$ The more serious the overflow, the higher the threshold - reaching that of necessity - for upholding the provisions. ${ }^{167}$ As suggested above, it is arguable that the pith and substance of the Clean Air Bill is regulation of GHG emissions to protect the environment and the health of Canadians. But the result, as suggested above, overflows into provincial powers over local works and undertakings that produce emissions, and the property and civil rights of their owners and operators. Specific industrial and natural resource sectors would be targeted. Carbon budgets that express the emission limits would be tailored to these sectors. The emission-credit trading system involves a mandated carbon price and credits that can be created not merely by emission reductions but by contributions to a technology fund and offsets - carbon reduction by a range of activities not directly regulated by the statute. The result is establishment of a specific foundation for a carbon management system in which firms in the target sectors will be compelled by economic necessity to participate. From an individual firm perspective, this would require creation of new business units and management systems - activities at the heart of local firm operations. There is a serious overflow, bringing core local matters - industrial and energy facilities and their operations - within federal jurisdiction. This is particularly so if these provisions are viewed in isolation from the remainder of the amended Clean Air Bill and the remainder of CEPA. ${ }^{168}$

\footnotetext{
${ }^{164}$ Assisted Human Reproduction Act Reference, supra note 89 at para 275, 125, 126.

${ }^{165}$ Hydro Quebec, supra note 73.

${ }^{166}$ General Motors, supra note 115 at 667-670.

167 Assisted Human Reproduction Act Reference, supra note 89 at para 127, 193, 275.

${ }^{168}$ Ibid. at para 275
} 
A number of criteria that may be used to assess integration and potentially justify overflow of legislative powers have been identified by the Supreme Court. These include whether a provision is remedial, whether it is limited, whether there is precedent for overflow of the subject matter in question and whether a head of power is - like the criminal law power ${ }^{169}-$ broad in scope. Jurisdictional overflow under legislation supported by broader powers is, in general, likely to be less serious. ${ }^{170}$ However, this list is not exhaustive, and in any event, these criteria are guidelines only, to be applied, as Justices LeBel and Deschamps pointed out in the Assisted Human Reproduction Reference, with "... reference to the context." ${ }^{171}$

Here, the emissions trading provisions in question are remedial only in a broad sense of remediating conditions that may give rise to harmful climate change. They are limited in their application to persons and commercial entities, but because these are particular local activities - sectors linked to provincial lands and resources - this, if anything, underlines the overflow. There is no precedent for federal environmental legislation reaching so deeply into regulating the industrial processes of particular local, provincial economic sectors. ${ }^{172}$ But most telling is that it is not clear that the prohibitions on release of GHGs beyond carbon budget limits depend on the provisions that authorize establishment of the emissions trading scheme. The trading scheme may make it easier for regulated individuals and corporations to comply with carbon budget limits, but there is no compelling evidence that a trading mechanism is a necessity for the overall scheme. ${ }^{173}$ It must be remembered that the trading scheme provisions were not included in the original Clean Air Bill. ${ }^{174}$ Moreover, it is at least arguable that if prices prescribed for credits created by payments into a technology fund are favourable, there may, as is the case under Alberta's scheme in which unlimited fund based credits are available, ${ }^{175}$ be very little credit trading activity. The result is that the emission trading provisions may not be considered necessary and therefore ancillary to the otherwise valid prohibitory scheme.

169 General Motors, supra note 115 at pp. 671-674, discussed in Assisted Human Reproduction Act Reference, supra note 89 at para 128-132 per Chief Justice McLachlin.

${ }^{170}$ General Motors, supra note 115 at 671.

${ }^{171}$ Assisted Human Reproduction Act Reference, supra note 89 at para 195.

172 Apart perhaps from water quality legislation, particularly the Fisheries Act based on the specific "Seacoast and Inland Fisheries" (Constitution Act 1867, s. 91(12) power.

173 Assisted Human Reproduction Act Reference, supra note 89 at para 276 where Justices Lebel and Deschamps observe that the scheme established by the prohibitory provisions of the Assisted Human Reproduction Act does not depend on the existence of the scheme for regulatory assisted human reproduction activities.

${ }^{174} \mathrm{Ibid}$. at para 276 where the judges note that the regulatory mechanisms were not included in the first assisted human reproduction bills, "which contained only absolute prohibitions."

175 Specified Gas Emitters Regulation, supra note 156, s. 8. 
Hogg concludes that properly drafted federal legislation for the regulation of GHG emissions would be upheld under the broad criminal power. He reviewed the Regulatory Framework for Air Emissions under the assumption that regulation would involve GHGs classified as toxins - the approach taken in the amended Clean Air Bill. ${ }^{176}$ He states that once emissions standards are prescribed by regulation, any firm not in compliance would be subject to criminal sanction and that this is a "perfectly safe exercise of Parliament's criminal law powers." 777 Though he acknowledges that the validity of "additional means of compliance" - emissions credits, emission offsets and a technology fund - raise specific questions, he concludes that they are nevertheless valid. His conclusion is that though these techniques are not typical of criminal law, they promote the same public purpose - protecting the environment by reduction of GHG emissions - as the specific prohibitions. ${ }^{178}$

Other commentators disagree. Hsu and Elliot see the problem of climate change as immediate and extremely serious, but do not find the directness required between the emissions of $\mathrm{CO}_{2}$ and the changing climate. ${ }^{179}$ This, along with the regulatory approach to cap and trade schemes, suggests to them that criminal law is not a likely candidate to uphold federal legislation.

All of this points to a conclusion that the federal government's approach in drafting the notice of intent and the amended Clean Air Bill does not result in clear criminal law power support. An equally plausible result is that what has been enacted is emission limits backed by prohibitions and penalties, plus a regulatory scheme that cuts deeply into provincial powers and is not fundamentally necessary to support the criminal prohibitions.

\section{CEPA, SECTION 330(3.2) AND THE COAL-FIRED ELECTRICITY GENERATION REGULATIONS}

The regulations are proposed under the authority of CEPA's Part 5 Toxics provisions following a 2005 Ministerial order under sections 90(1) and 332(1) that added GHGs, including $\mathrm{CO}_{2}$, to Schedule 1. ${ }^{180}$ This meant that under CEPA section 93(1) regulations were authorized to permit comprehensive regulation and management of CO2. Section 330(3.2), enacted in 2008, ${ }^{181}$ purported to add authority to target persons, undertakings or activities on the basis of factors, including production capacity, production or manufacturing technology and feedstocks.

Because of the close connection between the section 330(3.2) authority and the regulations' technique of targeting a specific subsector - electricity generation - using specific production technology and fuel (coal related to natural gas combined-cycle generation) and linking the performance standard to production capacity (emissions intensity), the constitutional reach of this section is assessed along with that of the proposed regulations.

\footnotetext{
${ }^{176}$ Hogg "A Question of Parliamentary Power", supra note 10; Hogg, "Constitutional Authority over Greenhouse Gas Emissions," supra note 10.

${ }^{177}$ Hogg, "A Question of Parliamentary Power," Ibid. at 6.

${ }^{178}$ Ibid. at 7.

${ }^{179}$ Hsu \& Elliot, supra note 47 at paras. 63-66.

180 Proposed coal-fired electricity generation regulations, supra note 2.

${ }^{181}$ S.C. 2008 , c. 31 , s. 5.
} 
First, as a result of $R$. v. Hydro Québec, ${ }^{182}$ the constitutional validity of the CEPA Part 5: Toxicity Assessment and Regulation of Toxic Substance provisions has been confirmed. But the Hydro Québec decision has limits. Justice La Forest recognized this in his judgment when he said:

"I quite understand that a particular prohibition may be so broad or allencompassing as to be found to be, in pith and substance, really aimed at regulating an area falling within the provincial domain and not exclusively at protecting the environment." 183

He went on to recognize that "certain types of legislation" may raise "very nice issues"184 concerning the scope of cabinet discretion to make orders beyond federal jurisdiction. Thus CEPA Part 5 and its regulations may exceed federal jurisdiction in their particular application. Though Justice La Forest was at pains to say that the Hydro Québec decision concerned CEPA's toxic substances assessment and regulation, and not merely specific orders concerning PCB substances, his discussion of CEPA suggested that he considered the act to be concerned essentially with regulation of toxic chemical substances. ${ }^{185}$ He noted that CEPA replaced the Environmental Contaminants Act, and that Environment Canada publications discussed the need to control widespread and often negligent use of chemical products that resulted in these substances entering the environment. ${ }^{186}$ This perspective on CEPA and the Hydro Québec majority judgment may explain why the federal government considered it necessary to add section 330(3.2). The latter was apparently thought to clarify that regulatory authority is not limited to addressing particular chemical substances by imposing general limits or requirements, but can include fuels and can specify classes of producers and their facilities, along with manufacturing techniques, production capacity and feedstocks. Regulatory jurisdiction was extended to industrial operations of defined classes of producers, thus moving a step beyond regulatory action aimed at substances themselves - the approach used in CEPA to deal with toxic chemical substances.

There are two possibilities for challenging the coal-fired electricity generation regulations' constitutionality. The first is to focus the attack on the regulation (and their s. 330(3.2) support) and direct the pith and substance analysis to the regulations. This approach is consistent with the desirability, noted in Assisted Human Reproduction Act Reference, ${ }^{187}$ of addressing pith and substance analysis to the impugned provisions rather than the entire act or its parts, in order to avoid potentially distorting federalism.

A second possible attack is to follow Hydro Québec by conceding that the pith and substance of the whole of Part 5, including s. 330(3.2) is environmental protection that relates to the federal criminal law power, but challenge the applicability of Part 5 and the regulations to matters within exclusive provincial jurisdiction. The analysis thus homes in on the classification part of the analysis and assesses the scope of the relevant federal head or heads of power.

\footnotetext{
${ }^{182}$ Hydro Québec, supra note 73.

${ }^{183}$ Ibid., para 130.

${ }^{184} \mathrm{Ibid}$.

185 Ibid., para 135.

${ }^{186}$ Ibid., para 136.

187 Assisted Human Reproduction Act Reference, supra note 89.
} 


\section{THE PITH AND SUBSTANCE OF THE REGULATIONS}

\section{Purpose}

Supported by section 330(3.2) of CEPA, the regulations create a specific performance standard for coal-fired electricity generating facilities expressed as a prohibition that links existing CEPA penalty provisions. ${ }^{188}$ The standard is connected in emissions intensity terms to average $\mathrm{CO}_{2}$ emissions from a combined-cycle natural gas generating unit, namely 375 tonnes of emissions for each gigawatt hour of electricity produced annually.

But unlike the amended Clean Air Act, there are no provisions for emissions or offset credit trading or a technology fund. Nor is a national or regional emissions target expressed. Rather the regulations create a schedule for achieving the generating facility performance standard by means of temporary exemptions reaching as far into the future as 2025. Commitment by particular generators to carbon capture and storage is a major exemption factor, ${ }^{189}$ as is the existence and term of power purchase agreements. ${ }^{190}$ It is apparent, and the published regulatory impact analysis statement makes clear, that the purpose is a transition away from high-emission coal fuel technology to lower emission natural gas and renewable energy techniques. ${ }^{191}$ A guiding principle is "balancing environmental and economic considerations," 192 with the need for low incremental energy investment and avoidance of stranded generation assets.

\section{Effects}

The effect for coal-fired electricity generators is not merely regulation of their production technology and fuel source. Coal fuel use is limited and eventually phased out; but the scheme does this in part by essentially requiring generators, if they want temporary exemption, to invest in a new business - carbon capture and storage. ${ }^{193}$ The regulations implement new energy policy that imposes requirements on a specific category of electricity producers. $\mathrm{SO}_{2}$ emissions will be reduced, along with other contaminant emissions from power plants. But the technique used is felt by generators as long-term energy policy implemented through required facility fuel and operating technology changes mitigated by carbon capture and storage projects.

\footnotetext{
${ }^{188}$ Proposed coal-fired electricity generation regulations, supra note 2, s. 3.

${ }^{189}$ Ibid., s. 8.

190 Ibid., s. 2, definition of "useful life".

${ }^{191}$ Ibid., Regulatory Impact Statement at 3.

192 Ibid., s. 8.

${ }^{193}$ Ibid., s. 8.
} 


\section{Classification}

If the pith and substance of the regulation is environment protection, specifically reduction of GHG emissions in order to combat global warming, then the federal criminal law power analysis from the Hydro Québec case is highly relevant. GHG emission reduction is widely recognized as promoting desirable environmental and broader societal values. It would qualify as a valid criminal law purpose - a necessary condition for application of the federal criminal law power. The core provision establishes the $375 \mathrm{Mt}$ per annum performance standard, linking this to the lower emission natural gas-fired generation technology. In form, it is a prohibition against exceeding this limit backed by CEPA penalty-necessary conditions for criminal law power jurisdiction. There may be some incidental spillover effects on subjects of provincial jurisdiction including property and civil rights and local works and undertakings. But this would not affect the federal jurisdiction conclusion.

If, however, environmental protection through reduction of GHG emissions is accepted as the pith and substance of CEPA Part 5, it is possible that effects on electricity generation facilities otherwise subject to provincial jurisdiction as outlined above, are too great. The key factors are targeting a specific energy subsector and regulating not by discrete prohibition, but through a scheme involving new long-term energy policy, implemented in a manner that addresses specific facility operations and management including essentially mandatory new technology and facilities involving carbon capture and storage.

On the other hand, if pith and substance concerns regulation of the operations and technology of a particular class of energy facilities, it is a short step to identify provincial property and civil rights and local works and undertakings as appropriate heads of legislative jurisdiction. Though framed as a prohibition and linked to a regulatory offence provision in CEPA, other factors suggest the closer connection to provincial powers. These include application to a specific class of energy generation facilities and provisions designed to restructure this specific industry in its technology and operations and even to essentially mandate a related industrial activity - carbon capture and storage. Also significant is the emissions intensity form of the standard, which has the effect of making the prohibition dependent on specific plant operations and technology without imposing real quantifiable limits on emissions.

The analysis above suggests at least a strong argument in favour of recognizing targeted energy facility regulation as the pith and substance of the regulations. If so, the classification analysis would, as outlined above, lead to the conclusion that the regulations are outside federal constitutional power. Their subject is properly within provincial powers, particularly property and civil rights and local works and undertakings.

\section{CONCLUSION}

The ill-fated 2006 CEPA amending bill entitled "Canada's Clean Air Act," as amended by the Legislative Committee on Bill C-30, is (the unimplemented Kyoto Protocol Implementation Act notwithstanding) the closest approximation we have of a comprehensive federal climate change statute. It included enforceable emission limits for major industrial emitters, particularly energy industry operators, emission credit and offset credit trading, and credits based on technology fund contributions. There is little doubt that direct and discrete federal GHG emission prohibition provisions are constitutionally valid as criminal law. But if constitutional attack focuses on the complex regulatory compliance provisions, a different picture emerges - one that suggests that the amended Clean Air Bill was not within federal constitutional jurisdiction. 
Four Supreme Court of Canada judges in the 2010 Assisted Human Reproduction Reference have reminded us that the characterization of the leading features of those provisions should be as specific as possible and that the characterization and classification to appropriate heads of constitutional power should be consistent with the principle of subsidiarity. Targeting certain industrial sectors with emission intensity-based GHG emission limits that affect specific facility operations and introducing market instruments that modify prohibitions, suggests leading legislative features framed around local industrial operations and management effects rather than broad GHG emission-reduction goals. These local features point to classic provincial subjects including property and civil rights and local works and undertakings rather than federal criminal law or peace, order and good government.

Federal coal-fired electricity generation regulations proposed in 2011, based on CEPA's Part 5 toxics regulation provisions, would create a performance-based emission prohibition backed by penalties. This suggests potential criminal law constitutional jurisdiction.

However, the focus on a specific category of industrial facilities, the emission intensity standard based on links to alternative fuel and technology and a scheme designed to restructure the electricity generation industry over a long timeframe involving essentially forcing generators to invest in a related business - carbon capture and storage - reveal significant effects on provincial electricity generating facilities and their operations and management. There is a strong possibility that these effects would be recognized as the pith and substance or leading feature of the proposed regulations. This would result in the regulations being unconstitutional as in relation to provincial property and civil rights and local works and undertakings powers rather than federal criminal law. 


\section{About the Authors}

Professor Al Lucas has been a member of the Alberta Bar since 1968.

Before joining the University of Calgary in 1976 as a founding faculty member, Professor Lucas was at the Faculty of Law, University of British Columbia from 1968 to 1976. During his term with the U of C Law School, he has served as Executive Director of the Canadian Institute of Resources Law and as Associate Dean (Research \& Graduate Studies).

He has been a consultant and policy advisor to several government departments, and held numerous professional appointments. At present, his professional involvements include serving as a Trustee of the Rocky Mountain Mineral Law Foundation, a Special Legal Advisor to the North American Commission for Environmental Cooperation, and as a member of the Governing Council of the International Bar Association's Section on Energy, Environment, Resources and Infrastructure Law (SEERIL).

His academic interests are concentrated on regulatory issues related to energy and environmental law, oil and gas law, constitutional law, and judicial review. Special teaching and research interests focus on Canadian international and comparative environmental and energy law, and include the project published as McHarg et al, "Property and the Law in Energy and Natural Resources", Oxford University Press, 2010, and (with Roger Cotton), "Canadian Environmental Law" (2nd), LexisNexis.

Professor Lucas is also an Adjunct Professor in the University of Calgary's Faculty of Environmental Design, teaches in the University's Interdisciplinary Masters Program in Sustainable Energy Development, and serves as an Acting Member of Alberta's Energy Resources Conservation Board. His awards include the Law Society of Alberta / Canadian Bar Association Distinguished Service Award for Legal Scholarship.

Jenette Yearsley is currently the Director of Regulatory Applications at AltaLink LLP. She completed this paper prior to joining AltaLink while she was a LLM graduate student in the University of Calgary, Faculty of Law. Prior to joining AltaLink, Ms. Yearsley was a Research Associate at the Canadian Institute of Resources Law (CIRL) from 2007 to 2010. Her research areas included sustainable energy; energy regulation; legal aspects of carbon capture and storage - primarily the potential regulatory regime and long-term liability; climate change; the Alberta Land Stewardship Act; and public participation in natural resources development. She is a past editor of the Canada Energy Law Service - Alberta (Thomson/Carswell). Before joining CIRL, she practiced law in Calgary and articled with the Courts of Appeal and Queen's Bench. In 2011, she completed her LLM degree. Her thesis addressed tort theory and liability rules for carbon capture and storage projects. She received her JD from the University of Calgary Faculty of Law in 2005 where she received the William A. McGillivray Gold Medal in Law. 


\section{ABOUT THIS PUBLICATION}

The School of Public Policy Research Papers provide in-depth, evidence-based assessments and recommendations on a range of public policy issues. Research Papers are put through a stringent peer review process prior to being made available to academics, policy makers, the media and the public at large. Views expressed in The School of Public Policy Research Papers are the opinions of the author(s) and do not necessarily represent the view of The School of Public Policy.

\section{OUR MANDATE}

The University of Calgary is home to scholars in 16 faculties (offering more than 80 academic programs) and 36 Research Institutes and Centres including The School of Public Policy. Under the direction of Jack Mintz, Palmer Chair in Public Policy, and supported by more than 100 academics and researchers, the work of The School of Public Policy and its students contributes to a more meaningful and informed public debate on fiscal, social, energy, environmental and international issues to improve Canada's and Alberta's economic and social performance.

The School of Public Policy achieves its objectives through fostering ongoing partnerships with federal, provincial, state and municipal governments, industry associations, NGOs, and leading academic institutions internationally. Foreign Investment Advisory Committee of the World Bank, International Monetary Fund, Finance Canada, Department of Foreign Affairs and International Trade Canada, and Government of Alberta, are just some of the partners already engaged with the School's activities.

For those in government, The School of Public Policy helps to build capacity and assists in the training of public servants through degree and non-degree programs that are critical for an effective public service in Canada. For those outside of the public sector, its programs enhance the effectiveness of public policy, providing a better understanding of the objectives and limitations faced by governments in the application of legislation.

\section{DISTRIBUTION}

Our publications are available online at www.policyschool.ca.

\section{DISCLAIMER}

The opinions expressed in these publications are the authors' alone and therefore do not necessarily reflect the opinions of the supporters, staff, or boards of The School of Public Policy.

\section{COPYRIGHT}

Copyright (C) 2011 by The School of Public Policy.

All rights reserved. No part of this publication may be reproduced in any manner whatsoever without written permission except in the case of brief passages quoted in critical articles and reviews.

\section{ISSN}

1919-112x SPP Research Papers (Print)

1919-1138 SPP Research Papers (Online)

\section{DATE OF ISSUE}

December 2011

\section{MEDIA INQUIRIES AND INFORMATION}

For media inquiries, please contact Morten Paulsen at 403-453-0062.

Our web site, www.policyschool.ca, contains more information about The School's events, publications, and staff.

\section{DEVELOPMENT}

For information about contributing to The School of Public Policy, please contact Candice Naylen by telephone at 403-210-7099 or by e-mail at cnaylen@ucalgary.ca.

\section{EDITOR}

Timothy Giannuzzi 


\section{RECENT PUBLICATIONS BY THE SCHOOL OF PUBLIC POLICY}

THE MYTHS AND FACTS OF FOSSIL FUEL SUBSIDIES: A CRITIQUE OF EXISTING STUDIES http:/ / policyschool.ucalgary.ca/files/publicpolicy/MCKENZIE\%20MINTZ\%20online.pdf Kenneth J. McKenzie and Jack M. Mintz | October 2011

HOMELESSNESS IN ALBERTA: THE DEMAND FOR SPACES IN ALBERTA'S HOMELESS SHELTERS http:// policyschool.ucalgary.ca/files/ public policy/homelessness\%20in\%20alberta.pdf Ronald Kneebone, J.C. Herbert Emery and Oksana Grynishak | September 2011

THE NEW SECURITY PERIMETER WITH THE UNITED STATES

http:// policyschool.ucalgary.ca/files/ public policy/flemming\%20sept011.pdf Brian Flemming | September 2011

INCOME SUPPORT FOR PERSONS WITH DISABILITIES

http:// policyschool.ucalgary.ca/files/publicpolicy/Kneebone_Disability_Study.pdf

Ronald Kneebone and Oksana Grynishak | September 2011

INVESTMENT REVIEW IN CANADA - WE CAN DO BETTER

http:// policyschool.ucalgary.ca/files/publicpolicy/Herman\%20Invest\%20Canada\%20online.pdf Lawrence L. Herman | September 2011

PLUCKING THE GOLDEN GOOSE: HIGHER ROYALTY RATES ON THE OIL SANDS GENERATE SIGNIFICANT INCREASES IN GOVERNMENT REVENUE

http:/ / policyschool.ucalgary.ca/files/public policy/KMckenzie\%20comm\%20sept11.pdf

Kenneth J. McKenzie | September 2011

ENVIRONMENTAL BENEFITS OF USING WIND GENERATION TO POWER PLUG-IN HYBRID ELECTRIC VEHICLES http:// policyschool.ucalgary.ca/files/ publicpolicy/enviro\%20hybrid\%20wind\%20energy.pdf

Mahdi Hajian, Monishaa Manickavasagam, William D. Rosehart and Hamidreza Zareipour | August 2011

A FRESH START ON IMPROVING ECONOMIC COMPETITIVENESS AND PERIMETER SECURITY

http:/ / policyschool.ucalgary.ca/files/publicpolicy/dburney.pdf

Derek H. Burney | August 2011

PIIGS “Я” US?

http:// policyschool.ucalgary.ca/files/ publicpolicy/US\%20debt\%20crisis.pdf

Stephen R. Richardson | July 2011

RHETORIC AND REALITIES: WHAT INDEPENDENCE OF THE BAR REQUIRES OF LAWYER REGULATION http:/ / policyschool.ucalgary.ca/files/publicpolicy/A_Woolley_lawregulat_c.pdf

Alice Woolley | June 2011

TAX IMPACT OF BC'S HST DEBATE ON INVESTMENT AND COMPETITIVENESS

http:/ / policyschool.ucalgary.ca/files/publicpolicy/tax\%20impact\%20BCHST\%20communique\%20c.pdf Jack Mintz | May 2011

SMALL BUSINESS TAXATION: REVAMPING INCENTIVES TO ENCOURAGE GROWTH http:/ / policyschool.ucalgary.ca/files/publicpolicy/mintzchen\%20small\%20business\%20tax\%20c.pdf Duanjie Chen \& Jack Mintz | May 2011

IS THIS THE END OF THE TORY DYNASTY? THE WILDROSE ALLIANCE IN ALBERTA POLITICS http:// policyschool.ucalgary.ca/files/publicpolicy/wildrose\%20online\%20final3.pdf

Anthony M. Sayers \& David K. Stewart | May 2011 